\title{
REPORT
}

of

Comittee on Thesis

The undersigned, acting as a Committee of the Graduate School, have read the accompanging

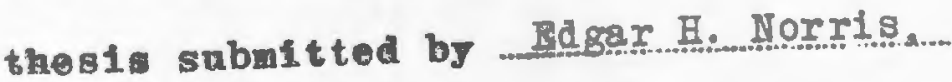

for the degree of Megter of Arts.

They approve it as a thesis menting the requirements of the Graduate School of tho University of Yinnesota, and recommend that it be accepted in partiol fulfillment of the requirements for the

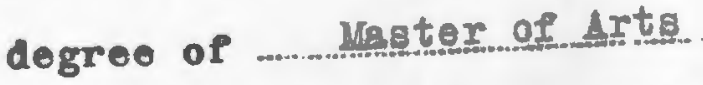

\section{C.m. Jackesan}

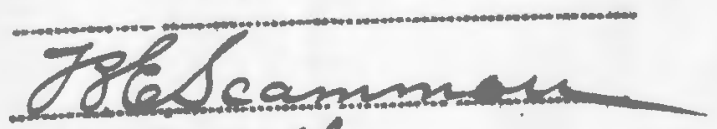

S.T.Rell. 


\section{REPORT \\ of \\ Committee on Examination}

This is to certify that we the undersigned, as a Committee of the Graduate School, have given Edger H. Norris

final oral examination

for the degree of Wester of Arts. We recommend

that the degree be

conferred upon the candidate.

Minneapolis, Winnesota.

Irar 30. 1916.

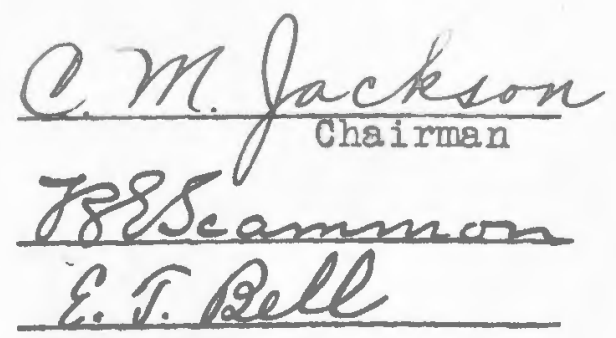


The Morphogenesis of the Follicles in the Human Thyrold Gland.
A Thesis

Submitted to the Freculty

$$
\text { of the }
$$

Graduate Sohool

$$
\text { of }
$$

The University of Minnesota

by

Edgar H. Wyoris

In partiel fulfillment of the requirements for

the degree

of

Mester of Arts.

1916. 
The Morphogenesis of the Follicles in the Human Thyrold Gland.

Edger H. Norris,

Institute of Anatomy, University of Minnesota.

Contents.

I. Introduction.

II. Iiteratare.

III. Material and Wethods.

IV. Morphogenesis of the Thyrold Follicle.

(a) Prefollicular Perlod.

(b) Follicular Period.

V. Discussion and Conclusions.

VI. Summary.

VII. Iiterature Cited.

VIII. Explanation of Flgares. 


\section{Introduction.}

In spite of numerous investigations, many questions concerning the development of the thyroid gland are still unsettled. This applies particularly to the morphogenesis of the thyroid follicles. The various and contradictory views in the literature on the development of the follicles are doubtless due in part to lack of adequate series of successive embryonic stages (especially of human embryos) available for study. The greatest difficulty, however, has arisen from the use of inadequate methods of investigation. The method hitherto almost exclusively used, that of direct observation of the microsoopic sections, is insufficient. By the use of reconstruotion methods, however, it has been found possible in the present study to reach a satiafectory solution of this difficult and important problem, at least regarding some of the more fundamental features.

This study was undertaicen in the Anatomical Laboratory of the University of Minnesota at the suggestion of Prof. C. M. Jackson, under whose supervision the work was conducted. I wish to thank Dr. Jackson for his valuable ald and criticisms.

\section{Iiteratare.}

The literature concerning the thyroid follicle will be considered in ohronological order. First, it is desirable to mention briefly the various views whloh have been held concerning the morphology of the adult (human) thyroid follicle. Then follows a brief statement of the conclusions concerning follicle development (incluaing also prefollicular stages), which have been arrived at by the observers who heve worked upon human material. A few observations, made on lower forms, which have seemed especlally pertinent 
to the present problem, are also included. Unless otherwise indcated, however, all statements refer to human material.

The follicular structure of the adult human thyrold gland has long been known. According to Bo6chat ('73), Lalouette (1750); who was the first to describe the minute structure of the thyroid gland, found vesicles which seemed to communicate with each other. Bardeleben ('4l) is sald by zeiss (' $7 \eta$ ) to have been the first to describe the adult thyroid follioles as isolated structures. Five jears earlier, however, Jones ('36) desoribed the thyrold follicles in considerable detail as completely olosed vesicles. Although there has been considerable disagreement concerning the structure of the adult thyroid follicle, the majority of the later observers have, like Jones, described the vesicles of the adult gland as closed, spheroidal bodies. Cruveilhier ('43), Virchow ('63), and

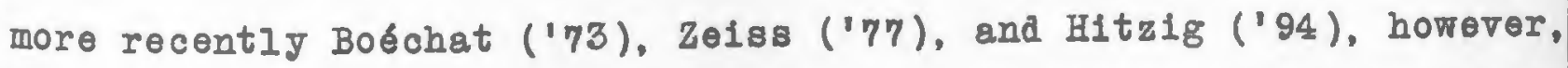
have followed Ialouette in desoribing the follicles as forming a gystem of branched and communicating cavities within the gland. Still others, like streiff ('97), have maintained that both branching forms and isolated vesicles occur in the adult gland.

Jones ('36), who was perhaps the first to describe the microsoopic structure of the human fetal thyro1d, found that in a fetas of $4-1 / 2$ months the cells of the gland had become partially arranged into sol1d, globular masses; but no vesicles were observed at this stage.

Remak ('55) deseribed in chiok embryos in the wall of the primitive sacoular, epithelial thyrold anlage the formation of thickenings which become separated and later give rise to the thyroid follicles. He also thought that the original saccular 
anlage might pergist for some time and form new secondary vesicles by a process of constriotion. In summarizing his observations upon the thyroid of chick embryos, he says: 
"Die Ipithelialblaschen, welche im erwachsenen Zustande die bindegewebigen Alveolen der Schllddrtise auskleiden, entstehen aus der Wand der primitiven Schildarusenblase. Tas aus der Hohle der letzteren wird, vermag ich nicht mit Bestimmtheit anzageben. Slcher 1st nur, das sie in dem Measse sich verengt und unkenntlich wird, als ihre Wand sich verdickt. Es ist daher moglich, dass sie nicht ganz schwindet, sondern die sie zunkchst begrenzende zellenschicht der Wand nicht zur Bildung von sekundären Epithelialblasen verwendet wird, sondern eine centrale Epithellalblase bildet, welche durch feinere Abschntrung in kleinere Blasen zerfellt." 
Bemak also described similarly the origin of secondary follicles, both by constrictions and by solld budding, in the thyroid of pis fetuses four inches and above in length.

Peremeschko ('67) stated that the structure of the thyroid varies with age. He noted the presence of vesicles and collold in mammalian fetuses, and described the division of primary into secondary follicles. Colloid is described as arlsing partly by secretion and partly by colloid metamorphosis of epithelial cells.

W. Muller (' $\eta 1)$, who considered the fully developed thyroid vesicles as closed globular bodies, described an earlier developmental stage in which, before the formation of vesicles, the gland consists of a network of cylinarical tubes.jin thpa $24 \mathrm{~mm}$. fetus and in decreasing numbers in later fetuses and even in a three jear old child. These tubes arise from solid epithelial cords by the development of a central lumen. The segmentation of tine tubes with the formation of the gland-vesicles is produced by ingrowth from the mesoblast. All of the early follicles have lumina which are distinctly outlined by clear cut margins. Mtller found that there is great variability in the shape of the thyroid follicles between the fifth fetal month and the third year of postfnatal life.

Horcicke ('80) found the thyroid gland of a four months' fetus to be made up for the most part of solld cell masses; but there is some change toward lumen formation in the central cells of these masses. Typical gland structure is found after the fifth fetal month.

wrlfler ('80) described the formation of follicles from solid masses of epithelial cells. Toward the end of the fetel period and after birth the peripheral cells of the groups dispose themselves in a circle. The central cells become at first granular, then 
degenerate and disappear in the pale, granular mass which fills the lumen of the vesicle thus formed.

I. Stieda ('8I) noted that the anastomosing epithelial cords ("Eplthelstringe") of the embryonic, mammalian thyrold are at first always solid, but that: 
"Im Laufe der Entwickelung tritt erst hie und da am Fnde eines Strangs ein Iumen und darauf eine ganz allmalige Abschnttrung des betreffenden Abschnitts des Drisenstrangs auf, es bilden sich sehr langsam, wie es scheint, die Blasen der Thyreoidea". 
Balfer ('81) described the fully formed follicle as spheroldal in form, but observed also branching follicles which are probably giving rise to secondary follicles by a process of alvision.

Wolfler ('83) described the process of later development in the human thyrold gland as centrifugal. He distinguished a cortical and a medullary portion, which are respectively joungest and oldest, least developed and most developed portions.

His ('85) in the thyrold gland of an embryo betwe on 16.5 and $22 \mathrm{~mm}$. in length, found as follows: 
"Be1 2ü sind zwar auch noch Gruppirungen der Zellen um langliche spalten herum vorhanden, daneben aber zahlreiche Complexe, die den Habitus eigentlicher Acini tragen. An joder zelle ist nunmehr ein leicht tingirberer k8rniger Abschnitt von elnem hellen (colloiden) geschleden, debel lagern sich die Elemente so, dass die die Kerne tragende kornige zone derselben die Peripherie des Acinus bez. des zellenrohres bildet, vogegen der helle Anthell nach einwärts gekehrt ist". 
Biond ('89) found that after filling, the (postnatal) thyrold vesicle discharges 1 ts contents, collapses and finally rearranges itself in the form of a number of small acinl which repeat the process. He held that the colloid arises by cell secretion, and not by cell degeneration.

Ribbert (189) described a centrifugal growth of the organ, and distinguished cortical and medullary portions in embryos and newborn children. Follicles are formed by the outgrowth of solid buds or sprouts from the old follicles. These buds are cut of $f$ by the connective tissue, and a lumen appears into which colloid is secreted.

Iustif ('91), who studied the thyroid gland in the pig and other animals, affirmed that colloid and follicles appear syachronously as the result of the same process, - the degeneration of the central cells of the preexisting solid masses.

Podack ('92) found well formed follicles in a fetus of five months. In some parts of the gland the follicular structure is only suggested and many cell-masses and cell-cords are present.

Marshall ('93) found that the thyroid in chick and frog embryos presents a stage in which the gland is made up of communicating, epitheliel tubes. In the rabbit he described the presence of outgrowths, some solid and some hollow, from the primitive opithelial anlege. Concerning the early development of the thyroid in the human embryo he stated: "At an early stage the lobes are excarated by a number of detached cavities, which become the vesicles of the adult thyroid".

zielinske ('94) found the structure of the thyroid in nowborm ohildren variable both in aize and number of the follicles, and also in the amount of solid cell masses. She remarked that: 
"Solche Lobuli, in denen mehr oder weniger central ein oder zwei mit cubischem oder cylindrischem Epithel versehene Drtsenlumina und im Uebrigen solide Zellhaufen slch finden, errinern an acinyse Drtisen und errechen den Gedanken, dass hier ein sich verästelnder Drlisenkanal vorliegt, als dessen Endbluschen die solide Zellhaufen gelten konnen." 
Htirthle ('94) described in the thyroid of young dogs scattered masses of interfollicular oplthelium, whose cells were supposed to migrate into the walls of the follicles and thus contribute to their growth. New (primary) follicles were also described as arising in the interstitial epithelial masses. Colloid is secreted into the angles between adjacent cells, which become separated and bound the lamen.

Anderson ('94) described secondary follicles (postnatal) arising from the collapsed opitholium of emptied follicles in various mammals. The new lumina are formed by cell-secretion of chromophile spherules, and not by degeneration of the central cells. No constriction or division of follicles was observed.

According to L.R.Metler ('96), the origin of small secondary follicles from the larger follicles, as described by Ribbert ('89) is clearly evident, even in the humen adult.

Tourneux and Verdun ('97) in a careful study of the branchial derivatives in the human embryo described the transformation of the (median) thyroid plate into a richly anastomosing network of solid epithelial cords by ingrowth of vascular connective tissue in a $14 \mathrm{~mm}$. embrjo. Similar changes take place later in the portion derived from the lateral thyroid anlage. The network of solid cords was likewise observed in embryos of $19 \mathrm{~mm} ., 24 \mathrm{~mm} ., 26 \mathrm{~mm}$., and in one of $37 \mathrm{~mm}$. In length. In enother of $37 \mathrm{~mm} .:$ "Ies cordons anastomoses de la thyrorde montrent quelques vesicules". The early follicles are described more fully in a fetus of $132 / 40 \mathrm{~mm}$." as follows: 
"La thyrolde se compose de cordons cellulatres ramifiés et nettement anastomosés qu'englobe une trame conjonctive lache dans laquelle rampent de larges capillaries. Ces cordons n'affectent pas une forme régulierement cylindrique, mais ils presentent sur leur parcours des renflements sphérlques ou ovordes, au niveau desquels ils sont creusés d'une oavité centrale; leur bpaisseur, de 30 a $40 \mu$ en moyenne, peut s'élever a $80 \mu$ au niveau des dilatations. Ils sont constitús par de petites cellules polyedriques tassés les unes contre les autres, et se disposant en un revetement oublque ou cylindrique peu éleve, au pourtour des excavations glendulaires. En beauooup de points, la paroi épithéliale d'une vésicule parait épaissie, et se souleve sous forme de bourgeons ploins faisant saillie a l'extérieur, et qui donnent a l'ensemble un aspect variqueux. 
Page 15.

Soulié and Verdun ('97) describe in a rabbit embryo of $15 \mathrm{~mm}$. the morphogenesis of the thyroid follicles similar to that found by Tourneur and Verdun ('97) in the human fetus.

Strelff ('97) made wax reconstructions of normal, adult human thyroid tissue, and found it to be made up of closed follicles, ovoidal or spindle -shaped. Branched forms due to budding or to secondary fusion were also described; some of these more complex forms he thought may represent persistent branching, --a continuation of the embryonic process. He concluded (from a study of the adult structure) that: 
"Die Glandula thyreoide des Menschen entsteht nach Art einer verkistelten tubalysen Drise. Am Sohluss der Entwicklung aber bilden sich an den Zellschlauchen vielfach Erweiterungen aus. Diese Erwelterungen werden als Vesiculae, noch nicht erweiterte Stticke der Schlluche als geschlossene Tubuli durch die wuchernden Geftsse und Bindegewebesztlge von einander getrennt." 
Schreiber ('98), in a fetus of three months, found the thyrold gland for the most part arranged into follicles which contained mach colloid.

Kürstelner ('99) in fetuses from 8 to $30 \mathrm{~cm}$. In length found the thyroid lobules made up of round or elongated, solid or hollow follicles. The lumine are few in number up to about $20 \mathrm{~cm}$, but in the older fetuses they are numerous and evenly distributed throughout the gland. In the four older fetuses $(17.5 \mathrm{~cm}$; $21 \mathrm{~cm}$; $22 \mathrm{~cm}$; $30 \mathrm{~cm}$.$) few vesicles measuring as much as 1 / 2 \mathrm{~mm}$. in diameter were found particularly in the lower and posterior part of the gland. Some brenching vesicles were also noted at $17.5 \mathrm{~cm}$.

(p.13)

Prenant ('Ol)astated that in the embryonic thyrold the solid epithelial cords are transformed into a network of tubes from which the follicles arise by a process of constriction.

Von Ebner ('02) found numerous well developed follicles in older fetuses and newborn. In the adult he described the follicles as of variable size, usually spherical in shape, but frequently elongated. Diverticula may occur, and two neighboring follicles may fuse. Between the follicles are found, even in the adult, frequent solid strings and nests of epithelial cells, which are in the majority during development.

Elkes ('03), who studied the thyrold in fetuses from 4-1/2 to 6-1/2 months in $88^{\theta}$, found thet 1t presents both solid cords and well developed folicles in variable number. In the newborn the earlier follicles have largely disappeared, leaving only a few at the periphery of the gland.

Hertwig ('10) (pp.444-446) described in the embryonic thyrold anastomosing opithelial cjlinders. These become tubuler; varicose dilations are by ingrowth of the adjecent connective tissue cut off 
to form the permenent follicles.

Isenschmid ('10) found that in the thyroid of children the gland grows not only by the increase in the size of the follicles, but by the formation of new follicles by two methods: budding and division. The lumen of the bud may be continuous with that of the mother follicle, or may arise independently. He found no evidence that follicles are formed from solid cell-mases (interfollicular epithelium) retained from the embryonel period.

Division of a follicle is produced by ingrowth of epithelial opurs from the side wall. Fusion of follicles may also occur. Follicles show the greatest conceivable variation in form, even in the same gland. A relatively large amount of desquamated epithelium was observed.

According to Hesselberg ('10): "Die Ausbildung der Thyreoldea in der fotelen Periode erfolgt durch zerfall der ursprtinglich soliden Zellplatte in solide Zellstrange. Diese schntiren sich zu BIbschen ab, die zuerst am kawdilen Pol auftreten". The normal otructure of the thyroid is established from the fourth fetal month on. Desquamation of epithelial cells was found in about half of the cases from the seventh to the ninth fetal month, and the follicles are almost entirely obliterated in the newborn. During the first week of postnatel life the follicles are reformed and increase in number by a process of buding.

Prenant and Bouin ('II) give an account of the development of the median thyroid anlage almilar to that given by Prenant ('0l). Bromen ('II) described in the differentiation of the thyrold anlage a tubular stage, trangformed by constrictions into beaded chaing and finally into separate follicles. 
According to Grosser ('12), the thyrold anlage begins to separate into solid cords in the human embryo of $8 \mathrm{~mm}$. In the 50 mm. fetus the cords, especially in the periphery, appear beaded. The beaded cords become divided into separate cell-masses, the anlages of the follicles. The lumina may appear as independent cavities (no tubular stage), before the follicles are detached, or they may arise later, eren in early postnatal life.

Simpson ('12) referred to the tubular structure of the thyroid and describes the gland of a seven months old child as tubular in character.

Aschoff ('13) stated that in the developing thyroid connective tissue separates round eplthelial balls from the anastomosing cords, and it is in these "balls" that the follicilar lumina develop.

Sobotta ('15) described the first lumina as appearing in the peripheral parts of the lateral thyroid lobes in a fetus $50 \mathrm{~mm}$. in length. The final breaking up of the cell cords into single groups, which will later form follicles, progresses very gradually, so that the final structure of the gland is arrived at only after birth. Interfollioular epithelium persists, which mey later give rise to follicles.

Kingsbury ('15) in describing the early development of the throid states that: 
"Iumina (follicular cavities) within the cell cords appear at about this period (32 mm.) and at first contain no demonstrablo colloid. In the $40 \mathrm{~mm}$. embryo some of the follicles contain colloid, although not much is present in the oldest embryo (48 mm.). At $10 \mathrm{~cm}$. the colloid-containing follicles are numerous." 


\section{Material and Methods.}

This study is based upon the collection of human embryos in the Anatomical Iaboratory of the University of Hinnesota. Several of the series used are in excellent condition for histological study. The embryos of the collection have been variougly fired and stained. The additional glands specially prepared have, for the most pert, beon fized in Formil-Zenker; embedded in paraffin, sectioned at $10 \mathrm{p}$ mounted serially and stained with alum-haematoxylin and eosin, or iron-haematoxylin and eosin.

Besides the specimens mounted in the collection, other glands from newborn children and from children in the early years of life were obtained at autopsy. These were used merely for purposes of comparison, and have neither been listed below, nor discusaed in this paper.

The following table shows the materials ased in this work. The embryos and fetuses used are arranged in the order of their crownrump lengths. "Minn.E.C." refers to the Minnesota Embryological Collection. An esterisk (*) following the number signifies that the thyroid gland elone was sectioned. Otherwise the entire embryo was arailable in serial sections. 


\begin{tabular}{|c|c|c|c|c|}
\hline $\begin{array}{c}\text { Serial } \\
\text { INo. }\end{array}$ & $\frac{\text { Minn. }}{\text { E.C.No. }}$ & $\begin{array}{l}\text { C.R. } \\
\text { Length } \\
\text { in mm. }\end{array}$ & Fixation & $\begin{array}{l}\text { Section } \\
\text { Thiokness } \\
\text { In Microns. }\end{array}$ \\
\hline 1 & H 6 & 6.0 & Zenker & 10 \\
\hline 2 & H 13 & 7.5 & Alcohol & 15 \\
\hline 3 & H 60 & 11.0 & Alcohol & 20 \\
\hline 4 & H 68 & 11.0 & Bouln & 15 \\
\hline 5 & E 134 & 12.0 & Alcohol & 20 \\
\hline 6 & B 1 & 15.0 & Alcohol & 12 \\
\hline 7 & E 23 & 15.0 & Alcohol & 10 \\
\hline 8 & स 18 & 15.5 & Formalin & 10 \\
\hline 9 & В 28 & 16.0 & Alcohol & 10 \\
\hline 10 & H 62 & 16.0 & Formel in & 20 \\
\hline 11 & E 58 & 17.0 & Formalin & 20 \\
\hline 12 & H 260 & 18.0 & Formalin & 15 \\
\hline 13 & H 24 & 19.0 & zenker & 12 \\
\hline 14 & H 2 & 20.0 & Pioro-sulphuric & 15 \\
\hline 15 & B 7 & 20.0 & $\cdots \cdots$ & 10 \\
\hline 16 & B 265 & 21.0 & Formalin & 20 \\
\hline 17 & E 3 & 22.0 & Zenker & 12 \\
\hline 18 & H 15 & 22.0 & Alcohol & 12 \\
\hline 19 & H 64 & 23.0 & Alcohol-formelin & 20 \\
\hline 20 & H 304 & 24.0 & Zenker & 20 \\
\hline 21 & H 56 & 24.0 & Aloohol & 20 \\
\hline 22 & H 5 & 25.0 & Zeniter & 15 \\
\hline 23 & H 21 & 26.0 & Alcohol & 15 \\
\hline 24 & H 29 & 26.0 & Aloohol & 12 \\
\hline 25 & स 99 & 26.0 & Aloohol-formalin & 20 \\
\hline 26 & H 48 & 27.0 & Bouin & 12 \\
\hline 27 & E 10 & 29.0 & Alcohol & 15 \\
\hline
\end{tabular}




\begin{tabular}{|c|c|c|c|c|}
\hline $\begin{array}{c}\text { Serial } \\
\text { No. }\end{array}$ & $\begin{array}{l}\text { Minn. } \\
\text { E.C.Mo. }\end{array}$ & $\begin{array}{l}\text { C.R. } \\
\text { Iength } \\
\text { in mm. }\end{array}$ & Fixation & $\begin{array}{l}\text { Section } \\
\text { Thickness } \\
\text { in Miorons. }\end{array}$ \\
\hline 28 & B 375 & 29.0 & Formalin & 10 \\
\hline 29 & 표 259 & 30.0 & Formalin & 20 \\
\hline 30 & H 108 & 30.0 & Zenker & 10 \\
\hline 31 & H 57 & 31.0 & Formalin & 20 \\
\hline 32 & H 16 & 33.0 & Zenker & 15 \\
\hline 33 & H 313 & 35.0 & Formalin & 20 \\
\hline 34 & H 122 & 39.0 & Formelin & 20 \\
\hline 35 & H 8 & 41.0 & Formelin & 12 \\
\hline 36 & 뵤 12 & 41.0 & Zenker & 15 \\
\hline 37 & ㅍ 121 & 46.0 & Formalin & 60 \\
\hline 38 & H 115 & 50.0 & Formalin & 40 \\
\hline $39 *$ & स 290 & 56.0 & Formalin & 10 \\
\hline $40^{*}$ & H 85 & 60.0 & Formalin & 10 \\
\hline 41 & ㅍ 26 & 65.0 & Formalin & 30 \\
\hline $42^{*}$ & H 285 & 66.0 & Formalin & 10 \\
\hline $43^{*}$ & H 81 & 83.0 & Aloohol & 10 \\
\hline $44 *$ & ㅍ 286 & 86.0 & Zenker & 10 \\
\hline $45^{*}$ & B 75 & 90.0 & Formalin & 10 \\
\hline $46^{*}$ & В 267 & 115.0 & Formalin & 10 \\
\hline $47^{*}$ & E 34 & 120.0 & Formalin & 10 \\
\hline $48^{*}$ & H 49 & 126.0 & Bouin & 10 \\
\hline $49^{*}$ & H 187 & 158.0 & Formelin & 10 \\
\hline $50^{*}$ & 且 381 & 163.0 & Formol Zenker & 10 \\
\hline
\end{tabular}


Page 24.

The ordinary reconstruction methods; both plastic (Born's waxplate method) and graphic, were utilized in the present study. In all cases where a determination of the follicular form or structure was attempted, special precautions were observed in making the reconstructions as accurate as possible.

The drawing a for reconstruction were made with the camera lucid on transparent paper. After the drawings were completed, those of successive sections were superimposed upon a tracing-table, and each epithelial structure in the section given a letter or number. The drawings were controlled by careful microscopic obserrations, to determine the frequently complicated relations of neighboring follicles. BJ this method it was possible to determine with certainty what the limits of any particular mass or follicle might be. 
IV. The Morphogenesis of the Thyrold Folliole.

(a) Prefollicular Period.

A brief consideration of the thyrold gland in the prefollicalar period is essential to an understanding of the follicular development. For it is during this prefollicular period that the anlages of the primitive follicles are derived from the original epithelial mass; and, to a certain extent at least, the size, form, and arrangement of the earlier follicles are thereby predetermined.

The earlier well-known stages in the development of the (median) thyroid anlage in the hupian embryo are not considered in the present paper. The original thyrold diverticulum becomes detached and transformed into a solid eplthelial plate, well shown in the $6 \mathrm{~mm}$. embryo (No.I of the present series). This and seversl succeeding prefollicular stages of the thyrold were carefully reconstructed by Born's wax-plate method, but for the present purposes It is unnecessary to figure or describe these models.

As is well known, the (medien) thyrold epthelial plate soon presents irregularities, as shown in the $7.5 \mathrm{~mm}$. embryo (No.2), and rapidly becomes transformed into what appears in oross-sections to be (as heretofore almost universally described) a network of anastomosing epithelial cords.

With the details of this process of transformation the present study is not concerned. One feature of the end result, however, which comes out clearly in the reoonstructed models, is that the cord-like appearance seen in the sections is largely an 1llusion. Pundamentaly the plate-like structare of the thyroid anlage persists for a considerable time, although somewhat modified by a complicated prooess of fenestration, splitting, and budding during the 
growth of the primitive eplthellal plate. The resultant structure consists essentially in a mass of irregular, branching and fenestra ted plates, for the most part longitudinally arranged (parallel to the long axis of the body), so that in cross-section they appear as "cords" of epithelial cells (fig.I). This type of structure, with varying degrees of complextty is found in the various prefollicular stages of embryos from about $10 \mathrm{~mm}$. to $22 \mathrm{~mm}$. in length. (Numbers $3,4,5,6,7,8,9,10,11,12,13,14,15,16,17,18$ of the present series).

Such a description, however, does not apply to the so-called lateral thyrold anlage (ultimobranchial body). As described by Tourneux and Verdun ('97) and others, this body long remains as a compact, deeply staining mass of epithelium (the " Inner condensation of Fingsburg '14) on the dorso-medial aspect of each lateral lobe. Whether in the human thyrold the lateral anlage later atrophies or finally becomes transformed into permanent thyrold tissue is still uncertain. This region is therefore purposely excluded from the following descriptions, which apply primerily to the process of morphogenesis in the structures derived from the medien thyrold anlage.

The thyroid gland in the final stage of the prefollicular period $1 \mathrm{~s}$ shown in a fetus of $22 \mathrm{~mm}$. (No.18). This stage will be described in some detail, in order to make clear the subsequent process of morphogenesis of the thyrold follicles. When studied in sections, the thyrold at this stage is seen to be made up apparently of epithellal "cords" whlch are interrelated in a complex manner (f1g.l). A loose, anastomosing network is thus formed, the interspaces of which are filled with a rascular mesenchymal tissue (fig.l). The "cords" are, in generel, only two cells in width, a 
feature characteristio of the thyrold plate and ito derivatives at various stages.

Upon reconstruction (11gs. 24 and 25 ) it is found that the epithelial network seen in sections, and described by so manj observers as consisting of "rods" ar "cords", is merelj a section of flat slab-like plates, or bands, representing portions of fenestrated plates. It is true that some few of the epithelial masses are actually cord-like in form, but by far the greater number are better described as bands or plates. A definition of terms is necessary at this point. The term "plate" will be used to signify a structure of relatively slight thickness, presenting expansive surfaces which are more or less smooth, and. which may or may not be perforated (fenestrated). A band is a narrow plate. Therefore a fenestrated plate may be considered as made up of a number of anastomosing bands. There is great variability in the way in which these plates and bands are arranged. Some are mere slabs, which may or may not be perforated; othersform 1rreguler prisms or rounded cylinders, which open at both ends into the surrounding mesenchyme. The length and width of these plates is also quite variable. In three respects, however, they are in general agreement. They are two cells thick; present fairly smooth surfaces; and are longitudinally plated. Within these epithelial bends (fenestrated plates) the primitive follicles of the thyroid gland develop. 
(b) Folifcular Period.

A thyrold follicle will be defined as a completely closed sac whose wall is usually made up of only a single layer of epithelial cells. This definition includes all the fertures of the follicle which may be regarded as absolute and constant. The size and shape of the follicle may vary, and great differences are found in these respects in follicles of the same gland as well as in follicles of fetuses at different stages. Typlcally the thyrold follicle may be considered spherical or spheroidel in shape; but, as will appear later, this type is subject to considerable variation. The term primary follicle will be used to include those follicles developing independently of preexisting follicles. The follicles derived from preexisting follicles, by budding or otherwise, are termed secondary follicles.

In the present series, the first primary thyrold follicles appear in a fetus $24 \mathrm{~mm}$. in crown-rump length (No.20). In this fetus the thyrold gland has essentially the same structure as has that of the last (No.18) described in the prefollicular period, 1.e. it is made up chiefly of longitudinally placed epithelial plates or bands, only two cells in thickness. But in this stage, the plates, which have in previous atages been characterized by comparatively smooth surfaces, now present surfaces which are more or less roughened by the appearance of scattered, short ridges (f1gs.26, 27 and 28). These ridges are never very extensive. They might therefore better be called hillocks or mounds than ridges. The are placed very irregularly with respect to one another, and may appear for the first time in any part of a plate, at its periphery or in a more central region.

When studied in cross sections ( $11 \mathrm{~g} .2$ ) it is found that these 
hillocks are the immedate anlages of the early thyrold follicles. It is further seen that the hillocks are apparently produced by the concurrence of four different processes in the epithelifin The first process is that of cell rearrengement, the second that of cell proliferation, the third that of absolute cell growth, and the fourth that of lumen formation. These processes, although described separately, may occur simultaneously.

The first departure from the two-oelled plate arrangement, in the process of follicle formation, is found in a rearrangement of the cells of the plate (figs. 2 and 5 ). The cell outlines can be made out only with difficulty in most cases. But in those places where they can be seen, they bound cells which are more or less columnar in form. The nuclei are ovoldal or elliptioel in outline and are placed with their long axes perpendicular to the surface of the plate. Here and there along the course of the plate (figs. 2 , 3 and 5), it will be noticed that certain of the nuclei have shifted their axes and have changed their relative positions. Certain of the nuclel have rotated thro an arc of 90. so that their long axes, in their final position, are at right angles to their original position in the plate. As a result of this shifting process, little circlets (really spheres) of nuclel are formed in the plate.

This shifting of nuclel is but the visible expression of the changed position of the cell. For while it is impossible to observe the cell boundaries in most cases, it is herdy probable that the nuclei shift their axes independent of the oftoplasm; mareover, the few faint cell-boundaries which may be made out show the same changes in position as do, the nuclei. Further, it is found (figs. 2 and 5 ) that at the point from which a nucleus has shifted toward the center of the plate, a slight depression appears 
on the surface of the plate, indicating that the cytoplasm has shared equally with the nucleus in the movement. From these three facts it may be concluded that the first process manifested in follicle formation is the shifting of the axes of cortain cells of the epithelial plate through an arc of 900. There is no evidence that the depressions on the surface of the epithelial plate are due to intasions or activity of the adjacent mesenchyme (figs.2,3,4, and 5 ).

This process results in the transiormation of the smooth surfaces of the bands (fenestrated plates) into surfaces which are somewhat roughened. The irregularities are apperently not, at first due to swellings on the plates, but rather to the slight indentation produced by the shifting of certain cells toward the center of the plate as above described. When studied in cross section (fig.2) such a plate appears as a sort of beaded chain, with alternate swellings and constrictions. But, as noted above, the initial swellings due to this process are only apparent and are actually not greater in thickness then is the plate in other parts of its extent where indentations have not jet occurred.

The extraordinary cellular activity of the epithelium at this stage is clearly manifested by the large number of mitotic figures to be seen. There is no section of the gland in the $24 \mathrm{~mm}$. fetus (No.20) which does not present severel cells in process of mitosis. But the localization of these mitoses is even more signiflosnt than is their number. A typical area is shown in figure 6 . It will be noticed that the nuclear figares in this area are found only in thos. places in the epithelial plates where actual thickenings on the plates are being formed. Therefore the little mounds which appear on the plates, as the immediate anlages of the early follicles, may 
be formed not only by the rearrangement of the already existing oells of the epithelial plates, but also by the formation of new cells as well. Consequently, it can easily be seen how the apperent gwellings on the plates, produced by the rearrangement of the existing cells, may be transformed into ectual swellings, by the absolute increase in number of the cells found in a localized area. These swellings become roughly spheroidal in form.

The third process referred to above is the absolute increase in size of the cells. While the cells are shifting their axes and proliferating, they are also growing in size. This fact results in the paradoxical appearance seen in figure 7 , where the solld, twocelled plates are found in some cases to be no greater in cross section than the one-oelled plate which surrounds the follicle lumen It might be thought that the cells do not actually increase in size, but only increase in height by a closer orowding together. But a study of figures $2,3,4$ and 5 will show that such is not the case. For the cells are not more closely packed together in the newly formed follicles than they are in the two-celled plate.

This progressive increase in the helght of the cells oorresponds to the progressive stages in the differentiation of the twocelled plate into newly formed follicles. So that the thyrold gland of a $30 \mathrm{~mm}$. fetus (No.30) presents in different regions epithelial cells varjing greatly in height. The lowest cells are found at the beginning of the process, in the two-celled plate; the highest being found at the other extreme, in the completely formed folliclo. Three of the four processes above mentioned as apperently infolved in the erolution of the follicle from the epithelial plate have now been revieved in detall. The formation of the lumen remains th be considered. Just precoding the appearance of the lumen, 
the spherule (in which it is about to develop) appears in cross section as a circlet of very tell columnar cells, whose nuclei are peripherally placed. This arrangement results in the formation of a striking picture. The nuclel are regularly placed at the periphery of the cirole and form a dark band, which surrounds an expansive, clear, central cytoplasmic portion. The magnitide of this cytoplasmic area and the sharp contrast between the two portions (in the stained preparations) are most striking features (f1gs, 2,4 and 5 ). It is in the center of this cytoplaamic area that the lumen makes its appearance $\widehat{a_{-}}$a ting spherical space outlined by a definite and regular margin. It is as though the cells had but drawa a little apart, so that their contral ends, instead of remaining in contact one with another, might be separated by an interval. The relation of the early lamina to one another is well shown in figure 8 which is a graphic reconstruction of a plate. It is important to note thap no tubular stage is found in the process of lumen formation. The Iumina appear as absolutely independent spaces.

As the luming first appear they apparently have no content; but undoubtediy they contain some substence which is not stained with the ordinary methods, and which increases in amount with the size of the follioular cavity. Certain of the larger lumina (not all of them), which are jerhaps older, are found to contain a hazj, granular substance. Typlcal collo1d does not appear until later in the $60 \mathrm{~mm}$. atage (No.40).

The various possibilities as to methods by which the follicular lumen may arise will be considered later in the discussion.

From the time of their first appearance, considerable var1ability in the alze of the lumina found in any particular gland is to be noted. The first isolated follicles are found in the more 
peripheral parts of the thyroid gland, and it is in these regions that they flrst attain large size and considerable complexity. For some time after the formation of follicles has begun, all stages previously described mag be found in different parts of the same gland, a considerable portion of which retains the irregular platelike type of structure charaoteristic of the prefollicular stages. In the foregoing account, the cell masses in which the lumina develop have been described as spherales whose cross section is oircular in outline. Whilo this is true for typical follicles and in most cases, some variation within comparatively narrow limits is found. Oroidal or somewhat irregular follicles occur, but these are not more numerous then would be expected in a rapidly growing tissue The foregolng descriptions of the early primary follicles have been taken in large part from observations made on two fetuses, one of $24 \mathrm{~mm}$. (No.20) and one of $30 \mathrm{~mm}$. (No.30). The excellent condition of these specimens has made possible studies of considerable detail. The members of the series (Nos. 21, 22, 23, 24, 25, 26, 27, 28, 29) intervening between these two, although not favorable for such Intensive studies, show substantially similar structure. These stages mag be summarized very briefly. The comparatively smooth epithelial plates of the prefollicular period have been trensformed into plates with rough surfaces. The roughened plates are but the early indication of the follicles about to be formed. With the progressively inoreasing number of follicles the plates are transformed into bands, which in turn give rise to groups of solid or hollow masses of cells. In the $30 \mathrm{~mm}$. stage, however, the thyrold gland is still largely made up of anastomosing bands (fenestrated plates), although some entirely isolated follicles are found. 
While the fetus is increasing in length from $30 \mathrm{~mm}$. to $50 \mathrm{~mm}$. the thyroid gland presents merely a continaation of the process above described; so that by the time the $50 \mathrm{~mm}$. stage is reached the band or plate formations are relatively insignificant, while the isolated epithelial masses make up the greater part of the organ. All stages in the breaking up of the bands or plates may still|be found, however. At this stage $(50 \mathrm{~mm}$.) the gland is therefore characterized by the presence of few eplthelial plates or bands, very many isolated, solid cell masses (anlages of follicles) and relatively few well developed follicles.

At $56 \mathrm{~mm}$. (No.39) the thyrold gland presents slightly more follicles then at $50 \mathrm{~mm}$. Not only are the follicles increased in nnmber, but they also show some changes in both size and form. In the previous stages the follicles have been relatively of about the avarage diameter
same size ( 35 to 55 microns), and typlcally spherical in form. But in this stage many of the follicles at the periphery of the gland have enlerged considerably and have departed from the more usuel spherical form of previous stages. This condition is more strikingIf seen in the next fetus of the series $(60 \mathrm{~mm}, 1 \mathbb{1 0} 0.40)$ where both increase in size and change in form of the follicles are very evident. The number of follicles at this stage appears about equal to the number of solid epithelial masses. Figure 16 is a graphic reconstruction of a number of epithelial masses from which follicles are being formed and of certain 1solated follicles. A study of figure 9 will show follicles sttuated at the peripheral portions of the lobe which are three or even four or five times as large as those of greatest magnitude located more centrally. The average aiameter of the centrally placed follicles is about 15 microns, while the average diameter of the follicles in the peripheral 
regions is approximately 55 microns. There is much loss absolute variation in the size of the central follicles then in those of the periphery. Centrally placed folltoles range from 13 to 17 miorons, while peripherally placed follicles range from 20 to 103 miorons in diameter. It will further be seen that these same large peripheral follicles are quite irregular in form. Instead of being circular in outline, they have a more or less regularly elliptical or ovoidal form, and may present a number of solid or hollow buds. Figures 13 and 14 represent reconstructions of a typical one of these large buding follicles, and figure 15 shows the same follicle in cross section. Figare 16 is a graphic reconstruction of a number of epithelial masses found in the thyroia gland of the $60 \mathrm{~mm}$. fetus (No.40) to demonstrate stages in the breaking up of the plates and the formation of isolated follicles, which are still present at this time.

The $65 \mathrm{~mm}$. fetus (No.4I) is the first member of the series in which practically no epithelial plates or bands are found. From this stage on through the remainder of the series the thyroid gland is made up almost entirely of independent solid or hollow, opithelia cell-masses. The stages (Nos. 42 and 43 ) included between this embryo and the one of $86 \mathrm{~mm}$. (No.44) mey be pessed over briefly with the statement that the processes of budaing and formation of new follicles just described are advancing rapidy parallel with the Increasing length of the fetus.

The $86 \mathrm{~mm}$. fetus (No.44) deserves special attention for $1 t$ oxhibits whet appears to be the oulmination of the buding prooesses referred to above. A study of figures 10 and 17 is sufficient to demonstrate the extreme complexity of the gland at this stage. The hollow and solid eplthellal masses are still about equal in number. 
The extreme variability in the form of the follicles is the most striking feature (f1gs. 10, 17 and 19), and the reconstructions (f1gs. 29 and 30 ) reveal more clearly the complextty of these struotures than is apparent in sections. Elongated follicles (figs. 10, 17, 29 and 30) with numerous hollow or solid buds, as well as numerous varleties of other more or less complex arrangements are to be seen. The whole picture is one of cotive growth. There is great variability in the size of the follicles, the largest being for the most part located in the peripheral zone; but the extreme variation in the follicular form makes absolute measurements for comparison of follicles of little value.

This condition of the gland prevails in the remaining members of the series, up to and including the $158 \mathrm{~mm}$. fetus (Nos.45,46,47, 48,49). There are but two differences to be noted. In the first place, as shown in figures 9, 10 and 11, the relative number of follicles is increasing from atage to stage, so that by the time the fetus is $158 \mathrm{~mm}$. In length, the follicles are far in excess over the solid, interfollicular messes. Secondly, the number of irregalar and complex forms, although still ocourring, it becoming fewer (fig.31).

The thyroid of the $163 \mathrm{~mm}$. fetus (No.50) has quite a different otruoture from that described for the members of the series just preceding (Nos. $44,45,46,47,48,49$ ). The irregralar and branching follicular complexes are comparatively few in number, while amall, spherical follicles make up almost the whole of the tissue. There are, however, a few solid, interfollicular epithelial masses still present at this stage. A comparative stady of figares 10 and 12 will show that the picture has changed from one in which great numbers of new follicles were being formed to one of almost complete 
organization. In other words, the epithelial structures of the tissue instead of being complex in their form have become relatively simple in charecter and for the most part are organized into small follicles.

My material from this stage on up to and including newborm ohildren show to a greater or less extent the process of epithelial desquametion described in the thyroid foll1cles by Elkes ('O3). Hesselberg ('10), Isenschmid (210) and others. Whether this process is physiological or pathologioal is as jet undetermined. Because the material at hand is not sufficient to warrant the arawing of ang conclusions in this matter, it is not listed with the materials nor discussed in the paper.

In four of the fetuses studied (Nos. $40,42,43$, and 44) a number of cyst-like follicles located in all cases in the lower and posterior part of the lateral lobe, were observed. Some of these measure as much as 200 microns in diameter. The size of these atructures is not much greater than that of some of the larger normally appearing follicles. But in structure the are quite different, having walls made up of very much flattened opithelial cells, whose nuclei cause the cells to bulge and are separated from one another by much greater distances than is the case with the nuclel in the more usual follioles. The lumina of these cjsts are quite regularly oiroular in outline and in many cases contain a granular substance. It is as though a follicle had been greatly distended, the cells of the wall being stretched and flettened. 


\section{Discussion and Conolusions.}

Remak's theory of the derivation of the thyrold follicles directly from the primitive saccular thyrold anlage has not been confirmed. In the prefollicular stages, the thyrold is by recent investigators quite generally described as assuming the form of 1rregular, anastomosing "cords" or masses of epithelium. This undoubtedly appears to be the case when sections of the glend are observed (flgs. 1 and $\eta$ ). But the reconstruction methods used in the present investigation reveel a surprisingly alfferent condition. It is found that, as a matter of fact, in the great majority of cases the cords are 1llusions and in reality are merely sections of fenestrated epithelial plates longitudinally arranged.

As to the further steps in the process of morphogenesis of the follicles from these ansatomosing "corda", widely divergent views have been held as noted in the section on "Ilterature". While differing considerably in detail, these views may be classified according to their prinoipal features. The morphogenesis of the primary follicles and of the secondery follicles wlll be congidered in their order.

Aocording to the apparently most widely accepted Fiew, based perhaps lergely upon preconceived ideas or theories ooncerning the evolution of the thyrold glend, there ere two distinct stages in the transformation of the epithelial "corda" into follicles. First the anastomosing "corda" acquire lumina, so that the gland becomes a more or less definite network of hollow epithellal tubes. The trbes then become oonstrloted (by ingrowth of vasouler connective tissue) Into spheroldal segments, each of which becomes a small sac or follicle whose cavity represents a portion of the originally con tinuous lumen of the tabe. This view hes been adrocated by 
W. Wuller ('7l), Marshall ('93) (in chlck and frog), Streiff ('97), Prenant ('Ol), Hertwig ('I0), Prenant and Bouln ('Il), Broman ('Il) and others. Some like streiff ('97) and Simpson ('12) have describel this branching tubular condition as persisting in part throughout fetal life and eren in postnatal life.

Other investigators, however, have described the lumine of the primary thyroid follicles as appearing directly and independently, w1th no preceding tubular stage. The anastomosing solid cell-cords are usually described as becoming varicose, with successive enlargements and constrictions, so as to present an irregular beaded appearance. Sooner or later each of these spheroldal swollen masses acquires a lumen and becomes separated so as to form an independent follicle. This method of follicle formation (with no tubular stege) has been described by Tournoux and Verdun ('97), Soulie and Verdun ('97), Grosser ('12), Aschoff ('13), Sobotta ('15), and Kingsbury ('15).

It 1s impossible to decide from direct observation of sections which of the preceding theories is correct. By reconstruction methods, however, both graphic reconstruction and wax-plate models, evidence has been secured in the present investigation which definitely alsproves the tubular theory and establishes in the human thyroid the independent origin ef the lumine of the thyroid follicles. The follicles, however, appear not in epithelial "cords" as described by earlier observers, but in the fenestrated epithelial plates above mentioned. The view that the thyroid is a modified branching tubular gland (Streiff, simpson, and others) therefore obtains no support from 1ts morphogenesis, aside from the initial stage of the primitive diverticulum. 
In the glends studied in the present series the first follicles appear in a fetus of $24 \mathrm{~mm}$. In length (No.20). This is earlier than the time of appearance described by most observers. His ('85), however, described follicles in a fetus (zW) whose absolute length is not recorded, but is pleced in series between fetuses of 16.5 and $22.0 \mathrm{~mm}$. in length. Kingsbury ('15) described follicles in a fetus of $32 \mathrm{~mm}$.; Tourneux and Verdun ('97) in one of $32.4 \mathrm{~mm}$; and Grosser ('12) and sobotta ('15) in fetuses of $50 \mathrm{~mm}$. These are the only cases found in the literature, where the presence of early follicles has been noted in fetuses of definite length. Several observers refer to the age of fetases in which the thyroid follicles appear, but in terms too indefinite to be of value for comparison.

Although by definition the prefollicular period ends abruptly with the appearance of the first follicles, it is not true that the structure of the gland undergoes any corresponding sudden change with the ushering in of the follicular period. The ppithelial bands (fenestrated plates) are only gradually replaced by the primary follicles, and otructures characteristio of the prefollicular period may be present through a considerable part of the follicular period, at least until the fetus has attained a length of $65 \mathrm{~mm}$.

Concerning the first three processes (rearrangement of the cells, cell proliferation, and increase in the size of the cells) involved in the development of the follicle from the epithelial plate, no further discussion is necessary. The fourth process, however, that of lumen formation, calls for further consideration. The follicular lumen might arise in various ways, which have been suggested by earlier investigators. Liost of the workers, however, do not mention the process by which the lumen of the follicle is 
formed.

Wrlfler ('80), and Iustig ('91) have described the formation of lumina in the solid cell masses by a defeneration of the more centrally placed cells. The present investigation does not support this view, however. In the first place none of the so-called central cells have been found; and secondly no evidences of degeneration have been observed in the primary follicles.

It might be supposed, as Eurthle ('94), and Anderson ('94) have suggested, thet the lumen is formed by the accumulation of colloid between the angles of the cells which compose the solid mass. Such a process would leave a collold-oontaining space surrounded by epithelial cells. But in no case in the present observations was "colloid" found within the very early follioles; although the accumulation of some other (precolloldal?) secretory product between the angles of the cells, might result in lumen formation. The fact is that the smaller lumina, which are probably the most recent in formation, have been universelly found to be devold of any demonutrable content, and that some of the larger and supposedily older lumina do contain a stainable substance. As to the natare of the precolloldal substance or substances, nothing definite is lonown.

One might suggest that the lumen could be formed by a degeneration or liquefaction of the central ends of the cells which later form its outline. In this case 1t would be expected that the early follicles would present a lumen outlined by an irregular or ragged margin. Without exception, however, the lumina of the early follicles are clearly outlined and marked off by a very sharp margin. 
Having stadied the way-in which the folliole forms within the plate, it is of further interest to determine the method by which the follicle frees itself from the plate and comes to take up an isolated existence. Earlier observers, in describing the formation of follicles from anastomosing rods or tubes, have lald emphasis upon the activity of the adjacent mesenchymal tissue as the factor operating in the separation of the follicles. In the present stady no definite morphological evidence appears in favor of this view. For as shown in the drawings (f1gs. 2,3,4,and 5) there is no special differentiation of the mesenchyme or increased vascularity in the regions in which follioles are being separated off from the plate. The evidence seems rather to indicate that the follicles themselves are the active agents in their separation. Thus as certain of the cells leave their original positions to assume a position more nearly in the center of the plate, the indentations preplously described appear on the plate. These mey be considered as weak points. And as the cells increase in number between these indentetions 1t is not diffloult to see how the increased pressure due to the increased mass might force certain follicles out from the row in whioh they formed and thus 1solate them from the parent plate. The vascular mesenchyme doubtless takes some slight part in the process, however.

As previously pointed out, the primary follicles mag not in every case be at once separated completely from the plate. Instead of being in all cases sharply outlined and spheroidal in form, small portions of the plate (epithelial tags) mag be left hanging to the follicle wall. The signiflcance of such epithelial tags is readiy understood when it is consldered how easily they might be mistaken 
for epithelial buds arising from the primary follicle in which secondary follicles were about to form. These structures will be mentioned later in the disoussion of the secondary follicles. It has been seen that there is no gharp line of demarcation between the prefollicular and follicular periods. Similarly, in the origin of follicles, the period of primary follicle formation is not sharply marked off from that of secondary follicle formation.

The number of thyrold follicles is apparently not absolutely established, or finally limited at any stage of development (as is the case, for instance, with the glomeruli of the kidney). In the earlier stages, the number of follicles increases by the formation of additional primary follicles. Soon, however, these primary follicles begin to give rise to secondary follicles (at $56 \mathrm{~mm}$.). In later stages the formation of primary follicles apparently ceases, although their occurrence even in the adult has been claimed, e.g. Hurthle ('94), Sobotta ('15), the new formed follicles being all secondary in character. Various methods of secondary follicle formation have been described.

1. Origin from buds or gprouts. Ribbert ('89), I. R. Mfliler ('96), Streiff ('97), Isenschmid ('10) and others have described this process. The bud is usurily described as a locel thickening of the follicle wall, which continues to increase in size by the proliferation of cells, until a solid bud, projecting into the strome is formed. Directly, through the concentric rearrangement of the cells, the form of the lumen can be made out, even while the young follicle is still in oontact with the mother folliole.

2. Origin from ollapsed follicles. Biondi ('89), snderson ('94), and others have described the process as follows. After fllling, the vesicle discharges its contents, collapses and finally 
rearranges itself in the form of a number of small acini which repeat the process.

3. Origin by fusion of follicles. Streiff ('97), v. Ebner ('02) Isensohmid ('10) and others have observed follicles which are apperently formed by the secondary fusion of two or more preextsting follicles.

4. Origin by division of follicles. Isenschmid (10) has described the formation of daughter-follicles by the growth of an eplthelial spur across the lumen of the mother folliole; and

Peremeschko ('67) hes noted the formation of secondery follicles by the constriction of the parent follicle.

In discussing my observations concerning the formation of secondary follicles in comparison with those of earlier observers, it may be said at the outset that nothing to support either the second or the third methods just outlined has been noted. These, however, have been described chiefly by previous observers upon postnatal material. The other two methods (budding and division of follicles), however, are in general agreement with the findings of the present investigation.

There appear to be three general methods by which secondary follicles arise in the fetal thyroid, the third of which might be regarded as a modifioation of the second. But each of these types is subject to a wide degree of variation, so that many intermediate and modifled forms ere found.

1. Solld epthelial buds may develop on the follicle wall (figs. 19, 28, 23). These may become separated from the parent foll1cle while in the solld state, or they may develop lumina while connected with the wall of the mother follicle, and aubsequently be constricted off. This method is essentially that advanced by 
Ribbert ('89), I.R. witliler ('96), Streiff ('97), and Isenschmid ('10), It is difficult, especially in the earlier stages, to distinguish these solid buds from the "epitheliel tags" reprenenting persistent portions of the original epithelial plates remaining attached to the earlier primary follicles.

2. Hollow buds whose cavities are continuous with that of the mother lumen are also found (figs.14 and 15). It might be suggested that these were originally solid buds whose lumen established a secondary connection with the lumen of the parent follicle. While It is diffioult to disprove such an occurrence, It would tend to reduce rather than to increase the number of follicles and seems

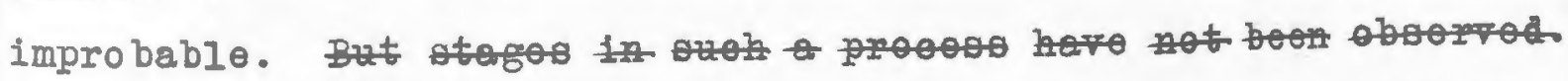
The parent follicle apparently sends off extensions or branches, which represent both the wall and the lumen and graduelly become constricted off to form new follicles. All possible stages in such a process, from the alightest outpouching of the wall to the finally separated follicle are easily observable (figs. $14,15,19,21$ and 23 ).

3. The third method of secondary follicle formation is the aimple division of the parent follicle somewhat as described by Peremeschko. The process appears similar to that of hollow bud formation. The follicle first takes on the form of an elongated ellipse which becomes constricted about its center. No cases of division by the ingrowth of epithelial spurs as described by Isensohmid (for postnatal stages) haze been observed in my fotal material.

Heving considered the primary and secondary follicles separatel it remains to consider them in their relations to each other and to the gland as a whole. 
The formation of the secondary thyrold follicles begins when the fetus has reached a length of about $56 \mathrm{~mm}$. From the $70 \mathrm{~mm}$. stage on the formation of secondary follicles progresses with such rapidity that the total number of follicles is verg greatly increased within a short period of time, and the relative number of primery follicles becomes progressively smaller.

It might be thought that such elongated, irregular, branched and budding forms as appear in large numbers in certain of the older members of the series (especielly in the $86 \mathrm{~mm}$. fetus, No.43) are derived from irregular, branching bends (fenestrated plates) retained from the prefollicular period. But the evidence disproves that view. After the appearance of the first follicles, the bands and plates are being progressively broken up until the gland parenchyma in a fetus of $65 \mathrm{~mm}$. is practically devold of such structures, and is almost entirely made up of isolated solld or hollow masses of cells. So closely does this resolution of the plates parallel the increasing length of the embryo up to $65 \mathrm{~mm}$. that it is very improbable that individual variations could explain the presence of these structures in such great numbers at the relatively late stage of $86 \mathrm{~mm}$. Further, as shown in figure 30, forms of all degrees of complexity may be found from simple spheroidal follicles to those of extreme complexty. The conclusion is therefore reached, that these structures, which are better described as follicular complexes than as follicles, are developmentelly only folliclos which have grown excesively and attained a high degree of complextit.

Such a rapid increase in the number of thyrold follioles as occurs in fetuses between 65 and $158 \mathrm{~mm}$. In length might be expected to produce a marked increase in the slze of the glend. But accordIng to Jackion ('09) the groith ourve for the prenatal thyroid gland 
shows no remarkable inoresse in the size (weight) of the gland during this period. These two observations, which at first may eppear contradictory, are readily explained when the size of the follicles is taken into account. The secondary follicles formed by bodding and division of the primary follicles are very smell and arise from follicles which are in most oases relatively of much greater size. So that while the number of follicles is greatly increased during this period, the glend mass is not correspondingly larger. As previously described, the formation of secondary follicles becomes less rapid before the fetus has reached $163 \mathrm{~mm}$. in length. From this point on, the number of thyrold follicles apperently increases but slowly, the subsequent growth of the glend being due rather to the increase in the size of the individual follicles, than to a further increase in their number.

The significance of the large cyst-like follicles desoribed in four of the fetuses is uncertain. Kürsteiner ('99) has desoribed the presence of similar follicles in four fetuses. The remarkable regularity with which they were found, in his oases as well as in those of the present series, located in the lower and posterior part of the lateral lobe of the gland, is a striking fact. Possibly they may be related to the cysts of the thyrold glend, frequently met in pathological conditions of postnatal life. 


\section{Sommery.}

By methods of reconstruction (both graphic and wax-plate), the complicated process of morphogenesis of the follicles of the prenatal human thyrold gland has been worked out and several mooted points definitely established.

1. The so-called "cords" forming the anastomosing network in sections of the thyrold (median anlage) in the later prefollicular stages represent chiefly sections of epithelial bands, two cello in thickness, and forming irregular fenestrated plates.

2. The frequently described stage in which the "cords" are transformed into an anastomosing set of epithellal tubes from which the follicles are derived does not exist. The process of follicle formation gives no evidence or indication that the thyroid hes been derived from a branching tubular gland.

3. The primary thyroid follicles arise directly as 1solated and independent structures from the opitheliel plates of the prefollicular period, by the zearrangement of cells, cell proliferation increase in the size of the colls, and lumen formation.

4. The primary follioles appear in fetuses slightly above $20 \mathrm{~mm}$. In length. The epithelial bands (fenestrated plates) have praotically diseppeared in a fetus of $65 \mathrm{~mm}$., but a few solid interfollicular epithelial masses are still present in fetases $163 \mathrm{~mm}$. in orown-rump length.

5. Secondary thyroid follicles are formed from preexiating follicles by three methods: by solid buds; by hollow buds; and by constriction of the parent follicle.

6. The first secondary follicles appear in fetuses about 56 mm. In length, but are formed most rapidly in stages when the fetus 
is between 80 and $158 \mathrm{~mm}$. long. After $163 \mathrm{~mm}$, the growth of the gland probably takes place largely by the increase in size of the individual follicles, rather than by increase in thelr number.

7. Large ejatio follicles were observed in the lower and posterior perts of four glands from the older fetuses. Their significance is uncertain, as is likewise the apparent involution of the follicles with desquamation of eplthelium observed in the later fetal and newborn stages. 


\section{IIterature C1ted.}

Anderson, 0.A. 1894 Zur Kenntn1s der Morpholog10 der schilddrlise. Archir f. Anat. u. Entw. S.177.

Aschoff, I. 1913 Schildartise-Normale Anatomie. In Pathologische Anatomie". 3. Aufl, Bd.2, S.928-9.

Baber, C.E. 1881 Researches on the Linute structare of the Thyroid Gland. Philosophical Trensactions, Vol.2.

Bardeleben, 1841 Observationes microscopicae de glandularum duct excretorio carentium structure degue earundem function ibus experimenta. Diss. 1naug. Berlin.

Blond, D. 1892 Contribution à l'6tude de la glande thyrolde. Arch. 1tal. de blol., T.17.

Bobchat, P.A. 1873 structure normale du corpe thyrorde. These, Paris.

Broman, J. 1911 Intwicklung der Schilddrtse. In"Normale und abnormale Entwloklung des lensohen". S.288-9.

Cruvelihier, J. 1843 Glande ThyroIde, In"Traite d'Anatomie Descriptive:" 2 Ed. T.3. Paris.

v.Ebner, V. 1902 Schilddrtise. In Kolliker's "Hendbuch d.

Gewebelehre: Bd.3.

Elkes, C. 1903 Der Bau der Sohilddrtise um die Ze1t der Geburt. Dissert., Konigsberg. 1. Pr.

Grosser, 0. 1912 The Development of the Pharyar and of the Organs of Respiration. In Keibel and Mall's "Fuman Embryology", V01.2, pp. $453 ; 468,469$.

Hertwig, 0. 1910 Die Schildarlse. In Hertwig's "Iehrbuch der Entwicklungsgesohichte des Menschen und der W1rbeltiere." 9 supl. pp. $444-446$. 
Hesselberg, C. 1910 Die menschlicho schildartise in der fotalen

Periode und in den ersten 6 Lbbons f. Path., Bd.5.

His, W. 1885 Anatomie tiensohlicher Imbryonen. Bd.III. Hitzig, 1894 Beltrgge zur Hlstologie und Histogenese der Struma. Diss. Zurich. (Cited by streiff 197).

Horcicka, J. 1880 Beltrkge zur Entwicklungs-und Wachstumgeschichth der Schildartse. Prager Zeitschr. f. Heilk., Bd.l. (Cited by Blkes 103).

Hurthle, K. 1894 Beitrkge zur Kenntnis des Secretionsvorgengs in der sohilddrtise. Pfltger!'s Archiv f. d. ges. Physiol., Bd. 56 .

Isenschmid, R. 1910 Zur Kenntnis der menschlichen Schildarltse im Kindesalter, mit besonderer Bertloksichtgung der Herkumft aus verschiedenen Gegenden im Hinblick auf die endemische Struma. Frankf. Zeitschr. f. Peth., Bd. б.

Jackson, C.M. 1909 on the prenatel growth of the humen body and the relative growth of the varlous organs and parts. Amer. Jour. of Anat., Vol.9, No.1.

Jones, C.H. 1836 Thyro1d Gland. In Todd's"Cjolopaedia of Anatomy and Physiology." Vol.4, pp.1102-1118.

Klagsbary, B.F. 1914 On the so-oalled ultimobranchial body of the mammalian embrjo: man. Anat. Anz., Bd.47, pp. 609-62\%.

1915 The development of the Iuman pharyax. Amer. Jour. of Anat., $\nabla 01.18$, p.329.

Kursteiner, W. 1899 Die Epithelkyrperchen des Monschen in Ihre Bezlehung zur Thyreoldes und Thymus. Anatomische Hefte, Vol.2. 
Lalouette, 1750 Recherches anatomiques sur la glande thyroide. Mémoires de methemątiques et de physiquo présentés á l'Academie royale des sciences (savants etangers). T.I, p.I59. (C1ted by Boéchat ' 78 ).

Iustig, A. 1891 Contribution á lo connaissance de l'histogenose de la glande thyrolde. Aroh. 1tal. de Blol. T.15. Marshall, A.M. 1893 Vertebrate Embryologj. Metller, I.R. 1896 Beltrg̈g zur Histologie der normelon und der erkrankten Sohildarlise. Ziegler's Beitrăge, Bd.19. Mrler, W. 1871 Über die Entwicklung der Schiladrtise. Jena. Zeitschr. f. Med. u. Naturw., Bă.6.

Peremeschko, 1867 Fin Beitrag zum Bau der Schildarise. Zeitschr. f. Wissensoh. Z001., Bd.17.

Podack, M. 1892 Beltrage zur Histologie und Funktion der Schildarlise. Dissert, KOnigsberg. 1. Pr.

Prenent, A. 1901 in Poirier et Charpy, "Traité d'anatomie humaine", T.4, p.13.

Prenant, Bouln et Millard 1911 Traité d'hlstologie, T.2, Histologie. p. 971 .

Remak, R. 1856 Unterguchungen tuber die Entwiokelung der Wirbelthiere. Berlin. S.122-123.

Ribbert, 1889 Ueber die Regeneration des Schildartisengewebes. Virohow's Arohiv. Bd.117.

Sohreiber, I. 1898 Beitrkge zur Kenntnis der Fntwicklung und des Baues der Glandulee parathyreoideae des Menschen. Archiv f. mikr. Anat., Bd.62.

simpson, B.T. 1912 Growth centers of the benign blastomata with especial reference to thyrold and prostatic adenomata. Jour. of Wedical Researoh, Vol.22. 
Sobotta, J. 1915 Anatomie der Schildartlse (Glandula thyreoldea). 29 Ileferung des "Handbrachs der Anatomie des Henschen" (von Bardeleben's). Bd.6, Abth.3, Teil 4.

Soulie et Verdun, 1897 Sur les premiers déreloppements de la glande thyrorde, du thymus et des glandules satellites de la thyrorde chez le lapin et chez la taupe. Jour. de l'Anat. et de la Phys. T.23.

Stieda, I. 1881 Untersuchungen ther die Entwickelung der Glandala Thymus, Glandula Thyroldea und Glandula Carotica. Lolpzig. Strelff, J.J. 1897 Ueber die Form der Schildartisen Follikel des Mienschen. Arohiv f. mikr. Anat., Bd.48, S.679. Tourneux et Verdun, 1897 Sur les premlers développements de la thyrorde, du thymus et les glandules parathyroidiennes chez l'homme. Jour. de I'Anet. et de la Phye. T.23. Virchow, R. 1863 Die krankhaften Geschwulate. Bd.3, 1. Helfte. wolfler, A. 1880 Veber die Entwicklung und den Bau der Sohilddrtse mit Rtlcksicht auf die Entwioklung der Kropfe. Berlin. (C1ted by Elkes '03).

1883 Ueber die Entwickelung und den Bau des Kropfes. Archir f. klin. Chirurgie. Bd.29.

Zeiss, 0. 1877 Mikroskopische Untersuchungen ther den Bau der Schllddrtise. Dissert., Strassburg, 1877.

Zielinske, M. 1894 Beltrkge zur Kenntniss der normelen und strumbsen Sch1ldartise des Menschen und des Hundes. Virohow's Archit. Bd.136. 
Fig. 4. A late stage in the breaking up of a plate into follicles. Note the epithelial tags (Ep.T.) attached to the walls of the first, second, and fourth follicles (counted from above downwards). Also note at elther extremity of the chain the solid epithelial masses (1nterfolliculer eplthelium, Inf.Ep.). B.V., blood vessel; Ies., mesenchyme. X 600.

Fig. 5. A small portion of the thyrold gland of a human fetus $30 \mathrm{~mm}$. long (No.30) bighly magnifled to show the microscopic structure of the plates. Note the rearrangement of nuclei and the indentations (In.) on the surface of the plate indicating that cells have shifted away from these points. Note the expansive central cytoplasmic areas (C.Cy.A.) in those regions where the cells are beginning to rearrange themselves and where no lumen (I.) has appeared. Cap., capillary; Mes., mesenchyma. I 600.

F1g.6. Semi-diagramatic drawing (camera lucida outlines) of a small portion of the thyroid gland of a human fetus $24 \mathrm{~mm}$. long (Bo. 20), to show the number and position of the mitotic figares (M. F.) in the plates which are in the process of follicle formation. B.V., blood vessel; R.Ep.Pl., section through a rough epithelial plate; S.Ep.Pl., section through a smooth epithelial plate. X 600 . Fig. 7 . Semidiagrammatic drawing (camera luoida outlinos) of a section through the right laterel lobe of the thyrold gland and nelghboring structures of a humen fetus $30 \mathrm{~mm}$. long (N0.30). Shows epithelial plates developing rough surfaces; also early follicles in various stages of separation from the plates. Note the general increase in widh of the plates as compared with those shown in figure 1. Cap., capillary; Fol.I.,folliclo lumen; S.Ep.Pl., smooth epithelial plate; R. Fp.Pl., rough epithellal plate; Hes.,mesenchyme; C., cartilago: I., laryax. X 200. 
Fig. 8. A graphic reconstruction of parts of two fenestrated epithelial plates from the thyrold gland of a human fetus $30 \mathrm{~mm}$. long (No.30) to show the relative position of the lumina (Fol.I.) as they appear in the plate. Note that in all cases the lumina are quite distinct and never connected with one another. Perf., perforaf tion. X 400 .

Fig. 9. Microphotograph of the left lateral lobe of the thyroi gland from a human fetus $60 \mathrm{~mm}$. Iong (No.40). Note the large irregular and budaing follioles in the peripheral regions. Note the smaller follieles and the large amount of solid eplthelial meterial in the central part of the lobe. Colloid in some follicles. A portion of the trechea is shown. X 69 .

Fig. 10. Microphotograph of the postero-medial portion of the left lateral lobe of the thyrold gland from a human fetus $86 \mathrm{~mm}$. long (No.44). Note the very numerous lerge irregular and budding follicles in the peripheral regions and the smaller follioles in the central parts. $>69$.

Fig. 11. Microphotograph of a section through the left lateral lobe of the thyrold glend from a human fetus $115 \mathrm{~mm}$. long (No.46). Note the general distribution of the follicles, the larger ones being located in the periphery. The section is teken through the entire lobe so that peripheral regions of the glend are shom both at the upper and lower part of the figure. $\times 69$.

F1g. 12. Microphotograph of a section taken from the periphery into the center of the left lateral lobe of the thyroid gland from a human fetus $163 \mathrm{~mm}$. long (No.50). Note the genersi distribution of the follicles, their relatively large number and uniform size. X 69. 


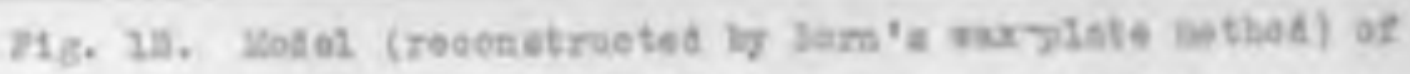

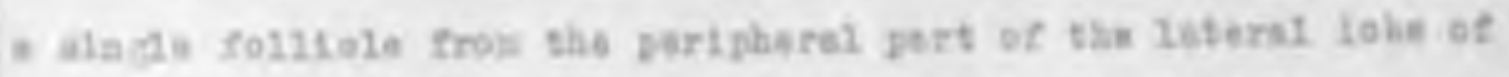

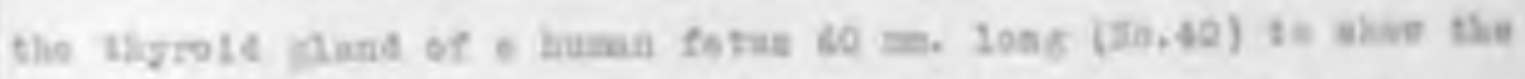

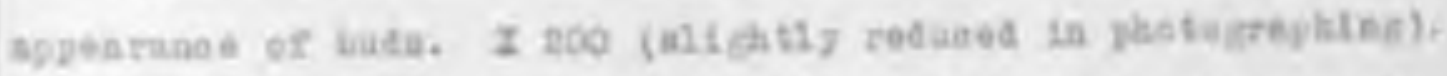

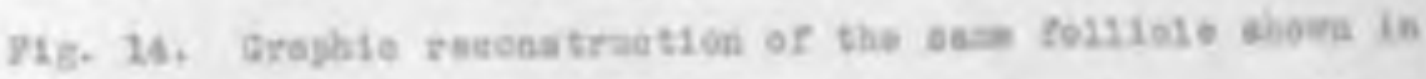

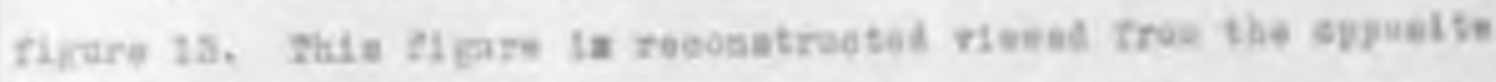

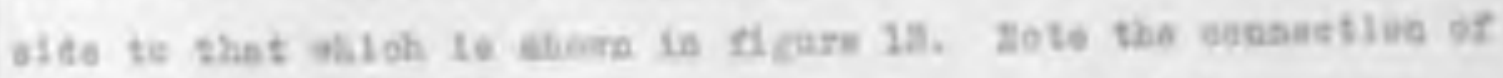

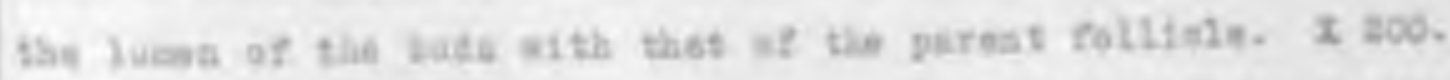

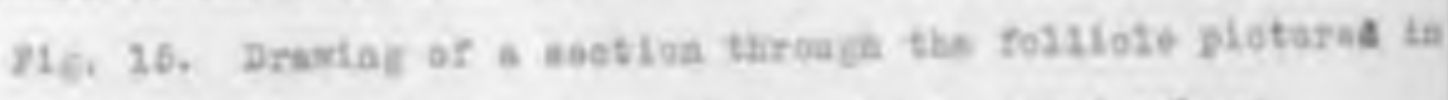

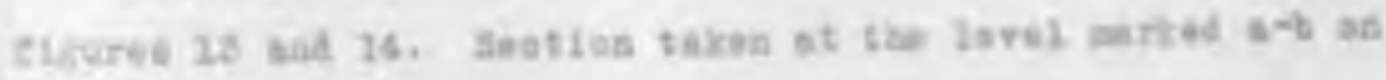
21 garo 25.

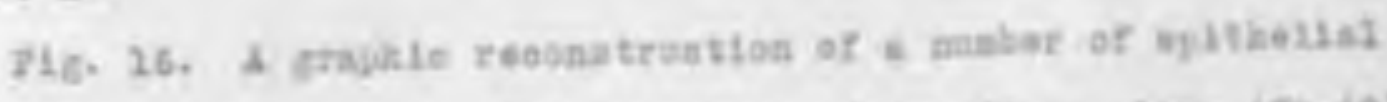

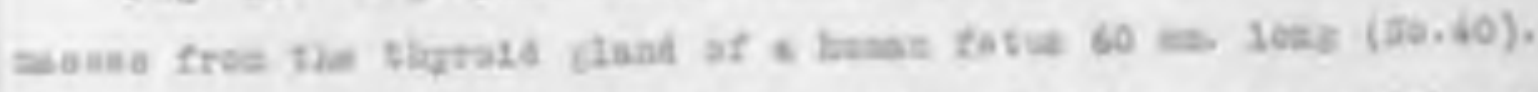

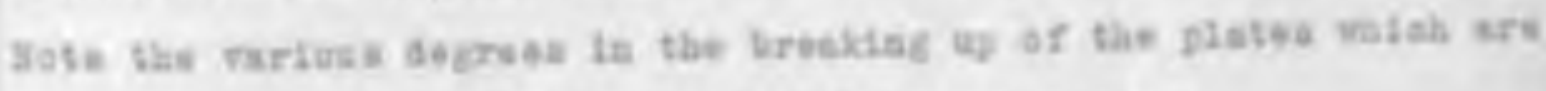

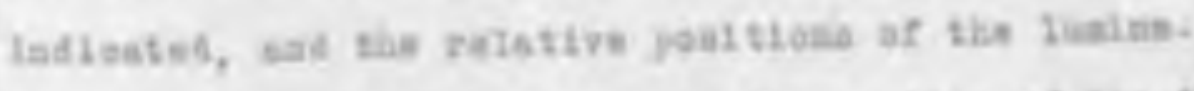

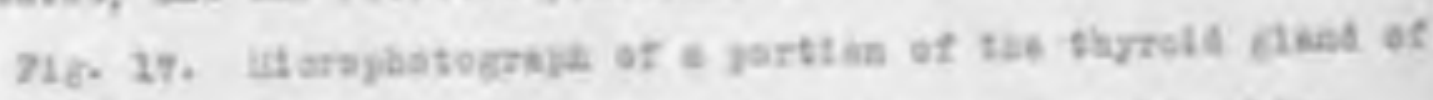

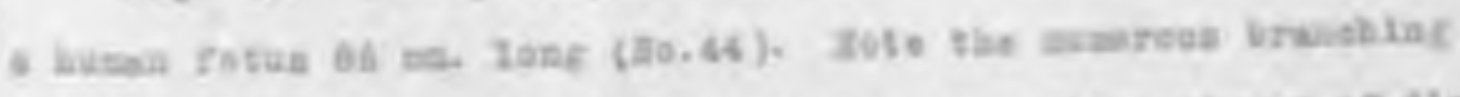

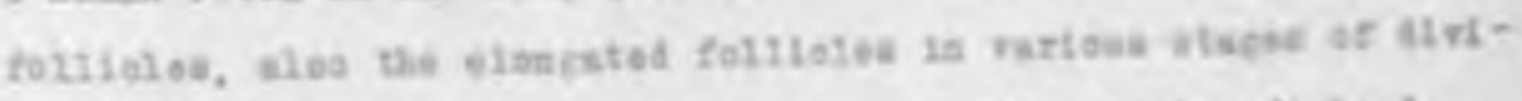

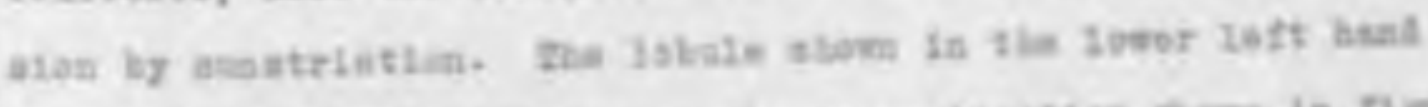

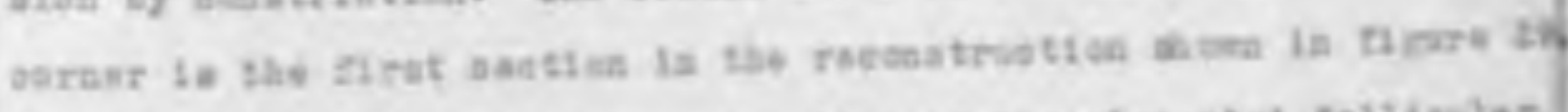

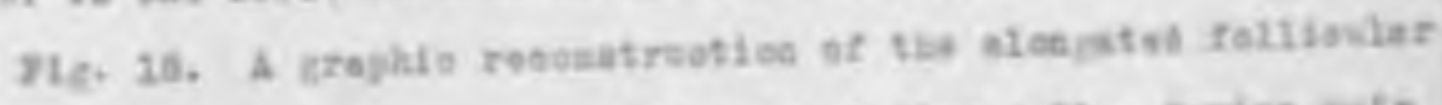

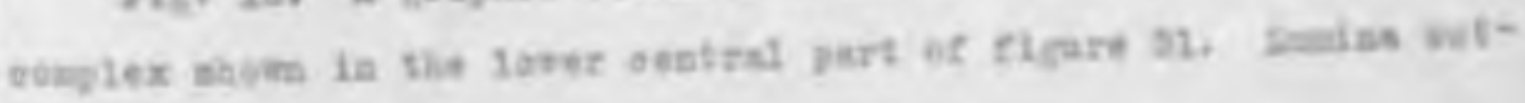
linet is rat. I 400 .

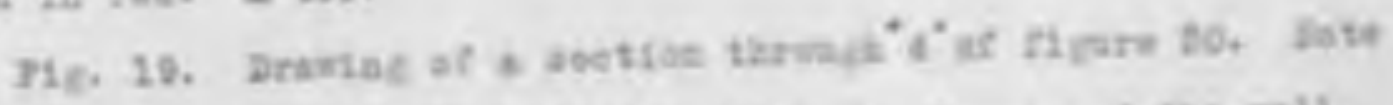

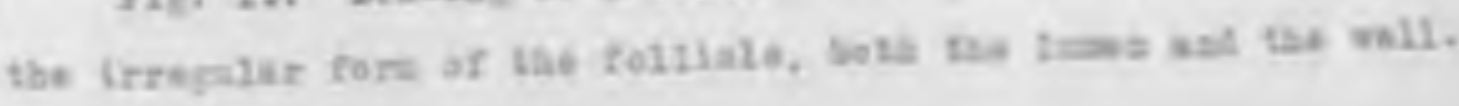
$x \leqslant 00$.

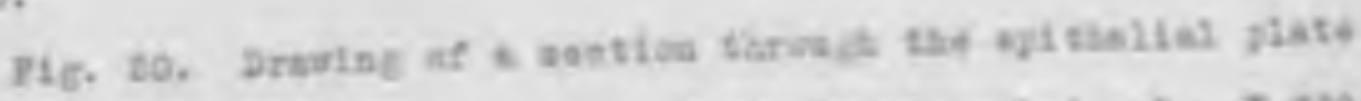

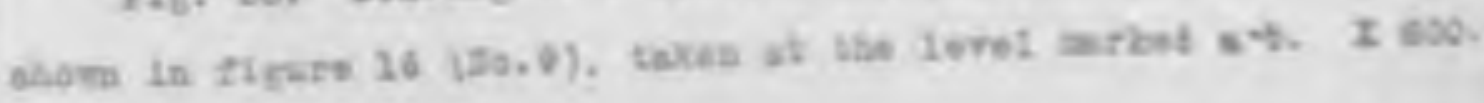


FIg. 21. Drawing of a small part of the thyrold gland of a humen fetus $60 \mathrm{~mm}$. long (No.40) to show the prectical impossibility of aistinguighing between solrd bads from the wall of a folitcle and epithelial tags. Also note the tendency shown for the follicle lumen to branch. I 600 .

Fig. 22. Drawing of a section of a follicle from the thyrola gland of a human fetus $158 \mathrm{~mm}$. long (No.49). Note the large number of solid buds. X 600 .

Fig. 23. Drawing of a small portion of the thyrold gland of a human fetus $163 \mathrm{~mm}$. long (No.50). The drawing shows early stages in the formation of solid buds. $x 600$.

Fig. 24. Model (reconstructed by Born's wax-plate method) of the left lateral lobe of the thyrola gland from a human fetus $22 \mathrm{~mm}$. long (No.18). Antero-leteral view to show the perforated (fenestrated) plates. Plates present relatively smooth surface $0_{1}^{a-b}$ indicates the level of the seotion shown in figure 1 , and the level at which the model was divided to show the relations pictared in figure 25. The carotid arteries are shown in the right hand side of the figure. X 300 .

Pig. 25. The lower section of the model pictured in figure 24. The upper portion hes been removed in order to demonstrate the relations to the gland mass of the appearances found in cross section. The separation of the two portions is made at the level of the section shown in figare 1 and indicated $(a-b)$ in figure 24. I 300 .

Pig. 26. Model (reconstructed by Born's wax-plate method) of the upper portion of the loft lateral lobe of the thyrold gland from a human fetas $30 \mathrm{~mm}$. long (No.30). Plates are more broken up than in flgure 24 and present surfeces which are relatively rough. The upper parathyroid (P.) is shown. Lateral view. I 200. 
21g. 27. liodol (reconstruoted by Born's waxplate method) of s psrt of a plate from the thyrold glawd of a humen fetus $50 \mathrm{~mm}$. long (Ho.30) st a higher magalficution, to demonetrate more exactiy than showis in Pigure 26, the sppearange and relstions of the mound forming on the suriece of the plete. The plane $\mathrm{a}-\mathrm{b}$ indestes the position of the seation shown in eigure 5. Iateral view. $x 300$.

Pig. 28. Ipithelial plate similar to thst shown in figure 27. Plane $a \rightarrow b$ indicates the position of the section $s$ hown in ficure 2 . DiB. 29. Wex reconstruction of a portion of a periphersi lobule of the thyroid gland of a human fetus $60 \mathrm{~mm}$. long (W0.40). DiE. zo. A series of follicles reconstruoted by Born's wszplite method to show the varying degrees of complexity. Takes from the thyrold gland of a human fetag $60 \mathrm{~mm}$. 10ag. (Ifo.40).

P1g. 81. Wax reconatruetion (Born's method) of a peripheral lobule of the thyrolt gland of a human fetus $158 \mathrm{~mm}$. $10 \mathrm{Dg}$ (Eto.49). 

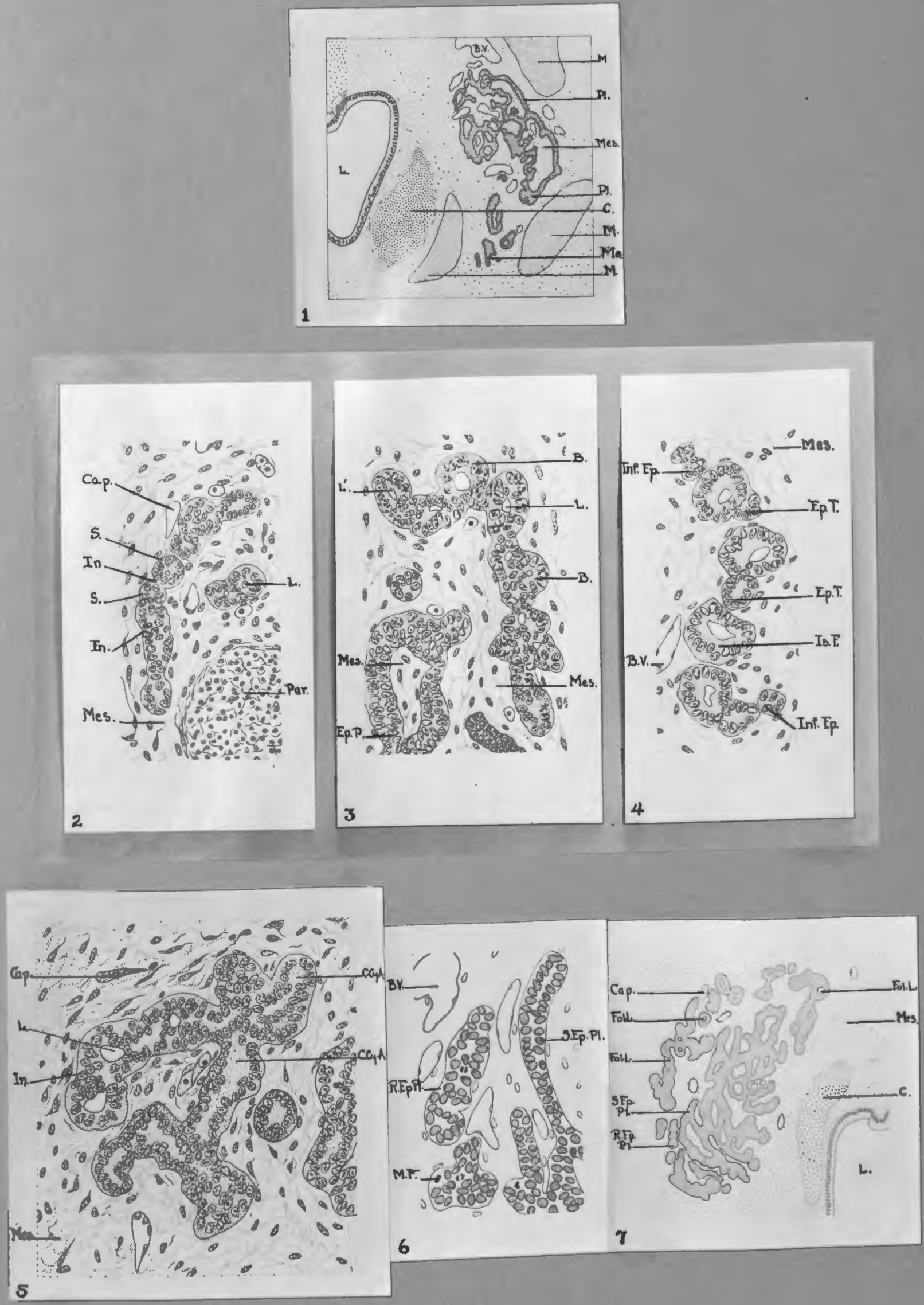

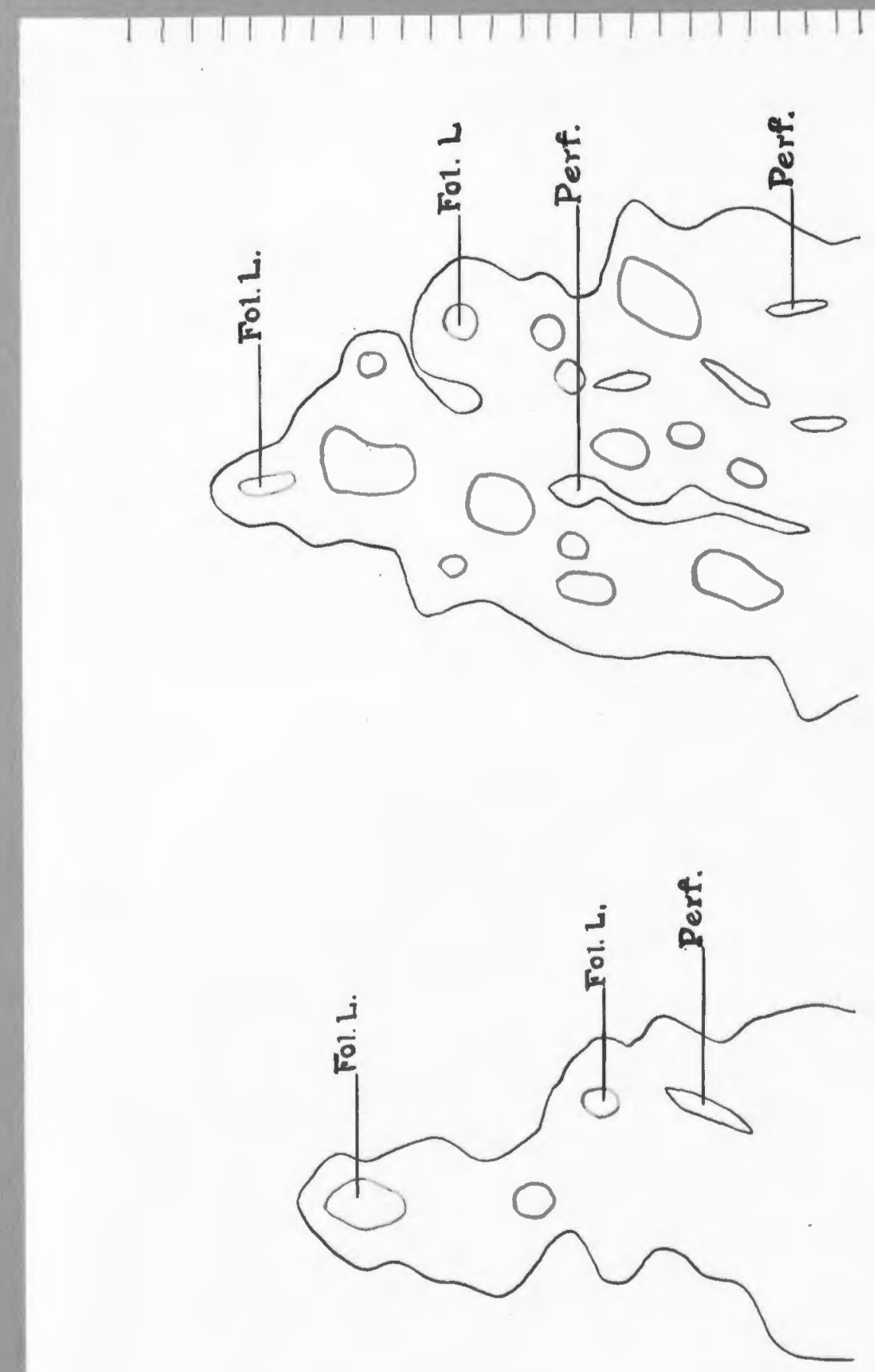

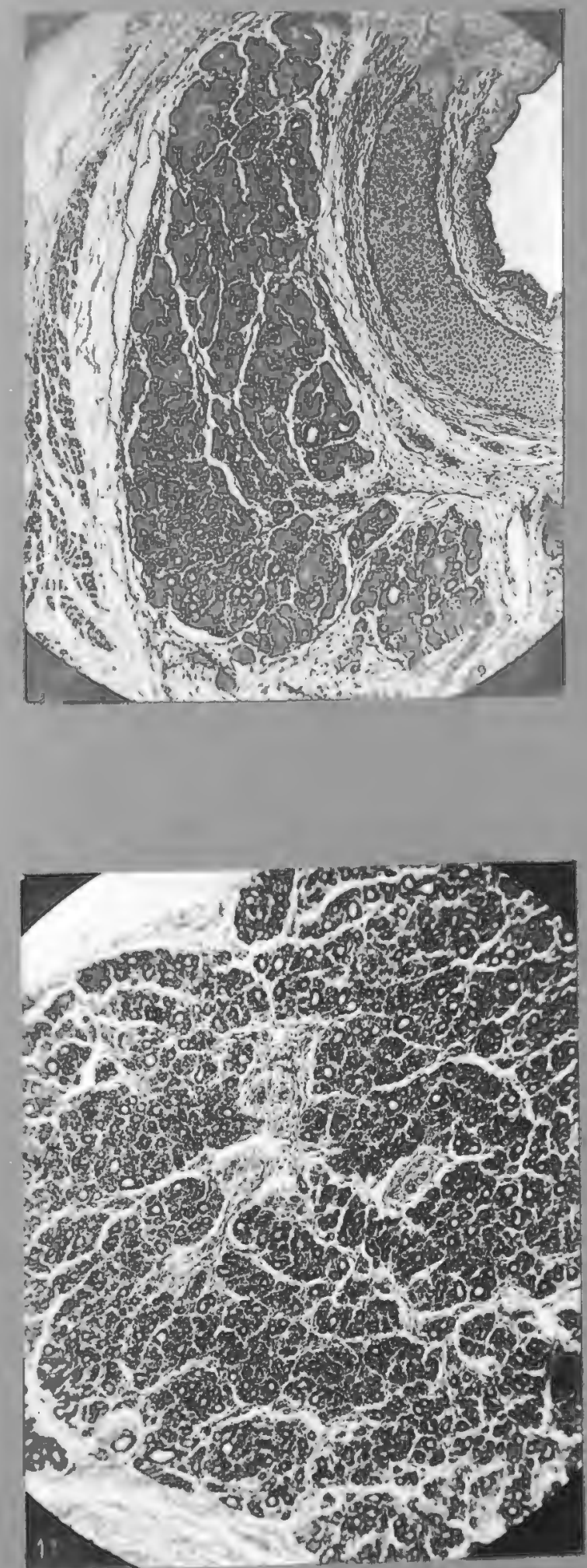
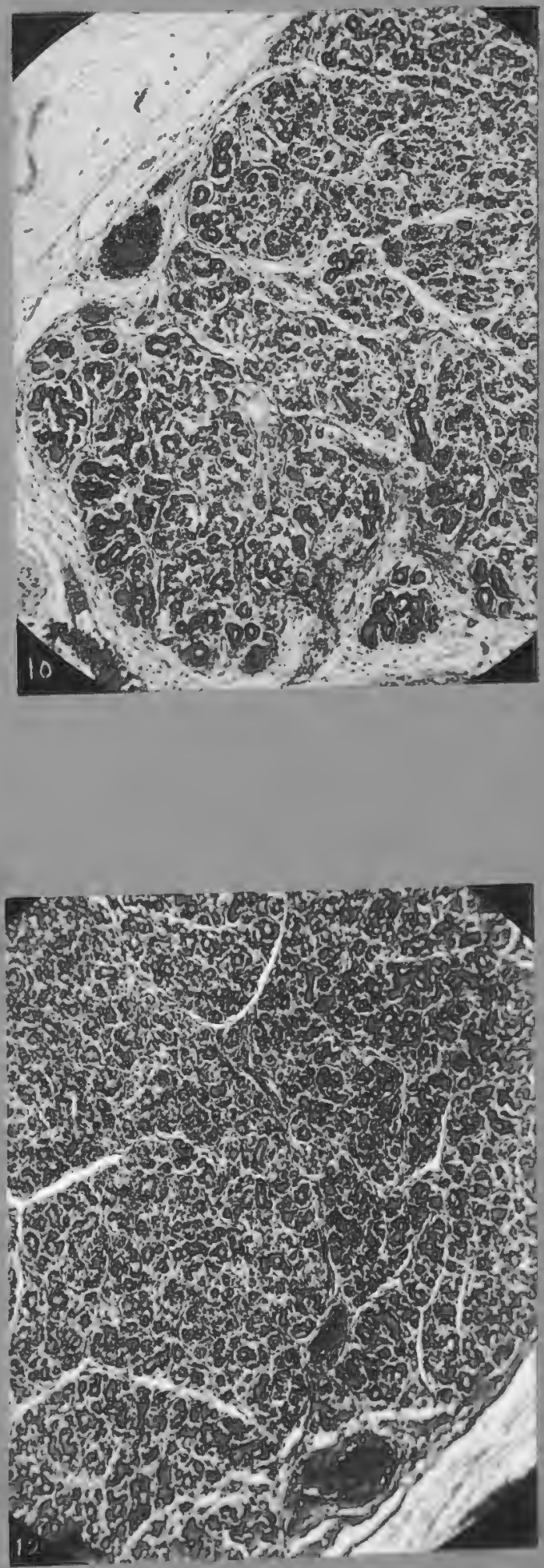

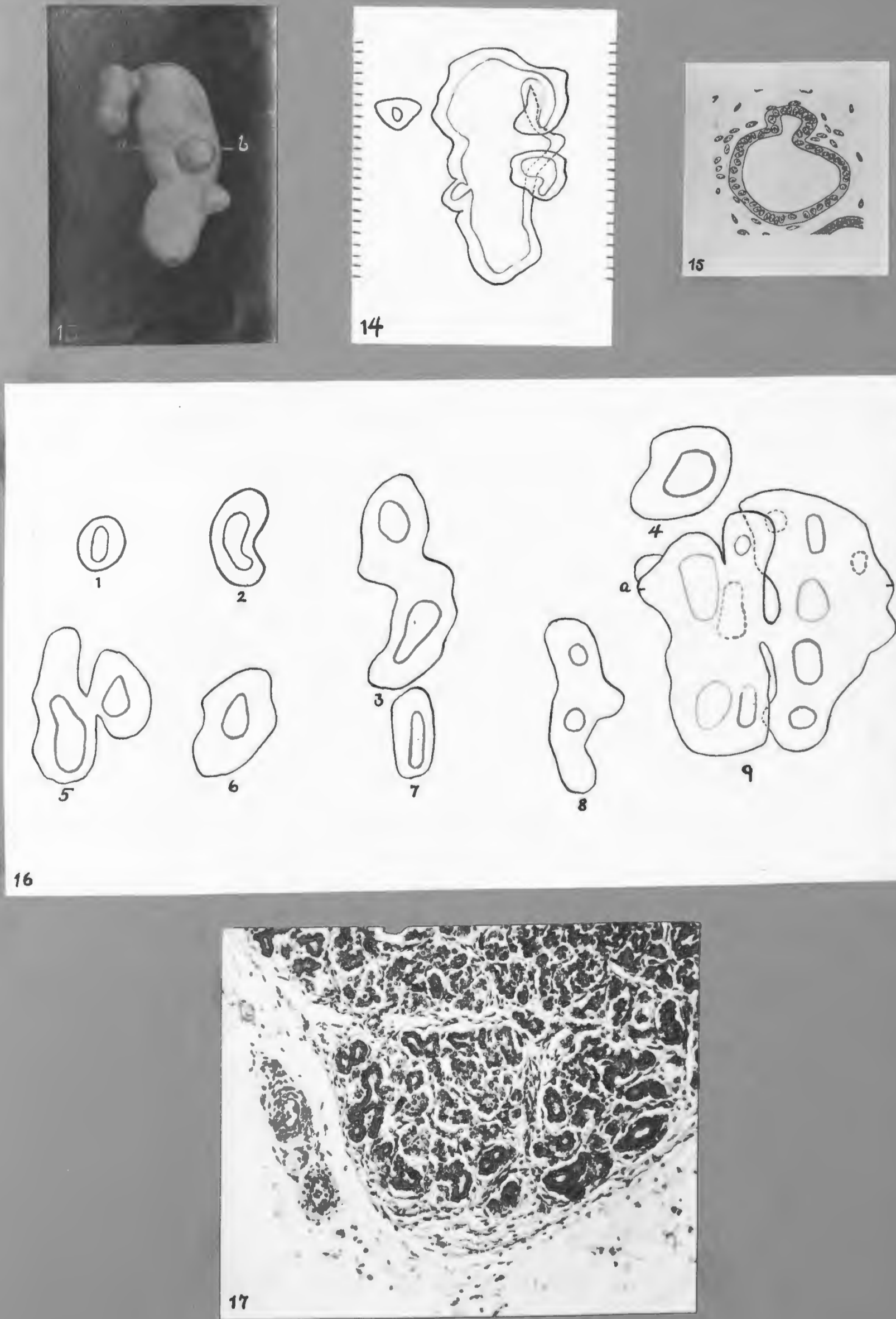


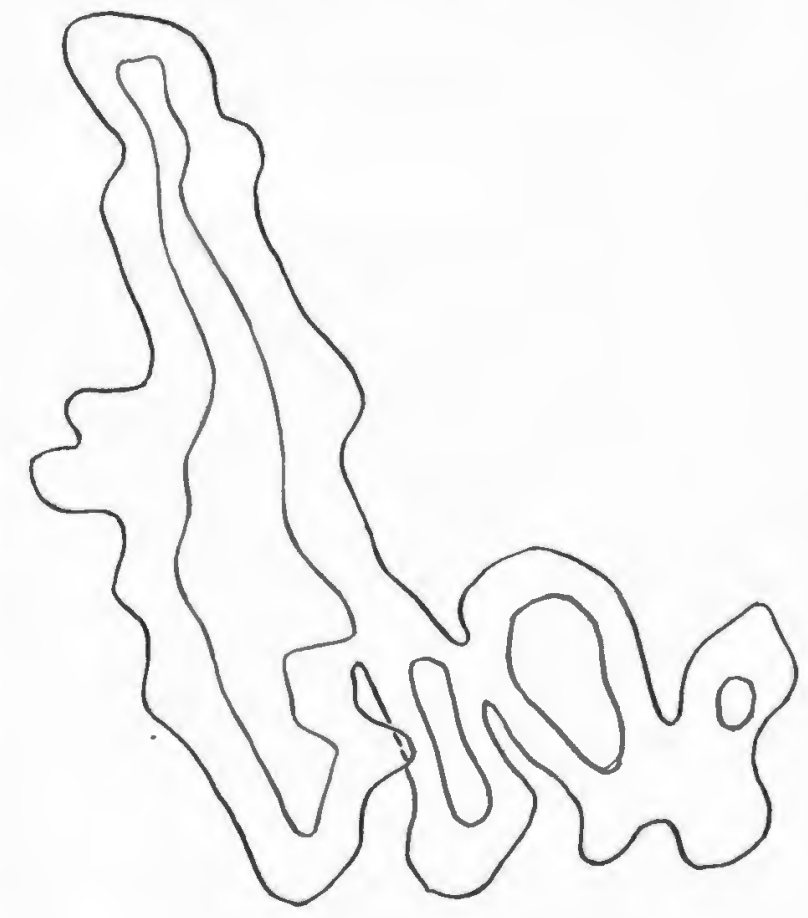

18
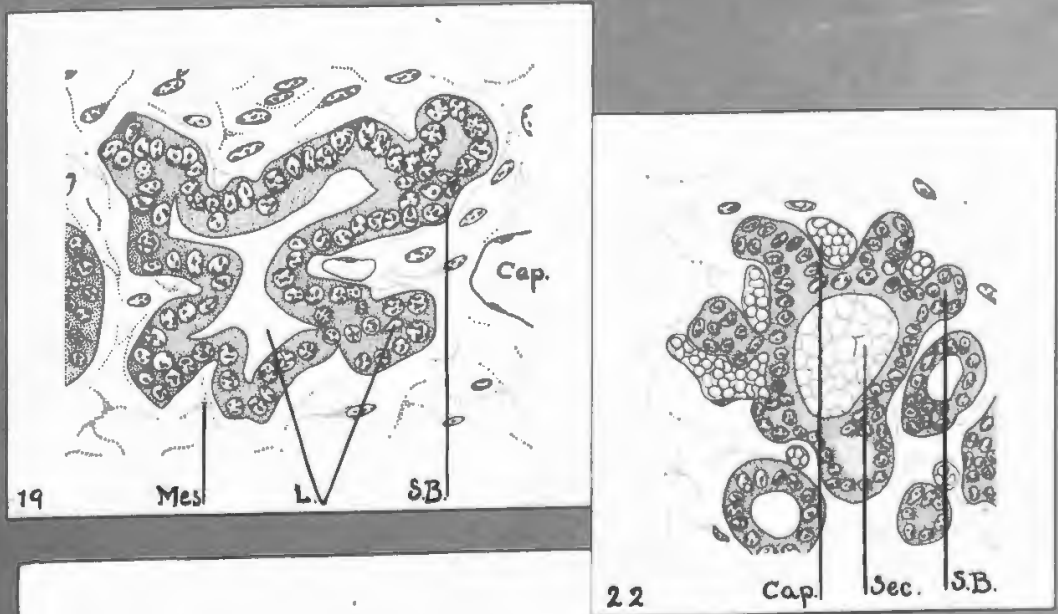

10000

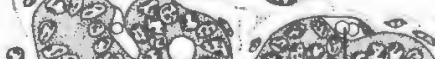

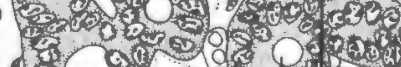

aror an mo

atos $-x^{0}=9$

Mes $\left.\left.\right|_{\text {Lap. }}\right|_{\text {Ep. I. }}$

20

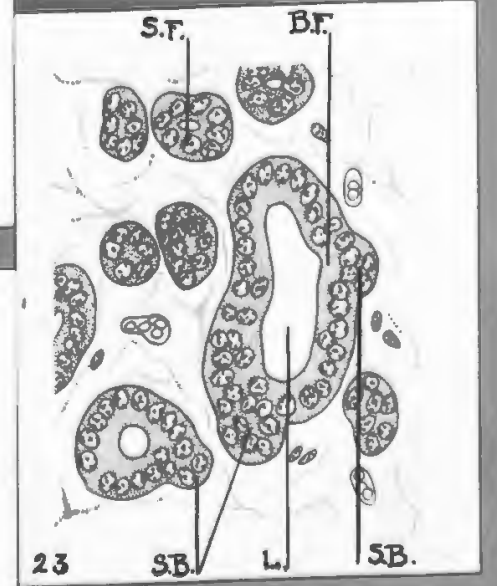

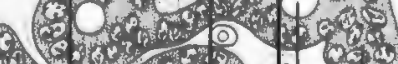

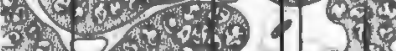

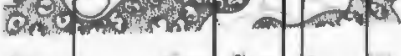

Secl Cap.l L. Ep.P1 

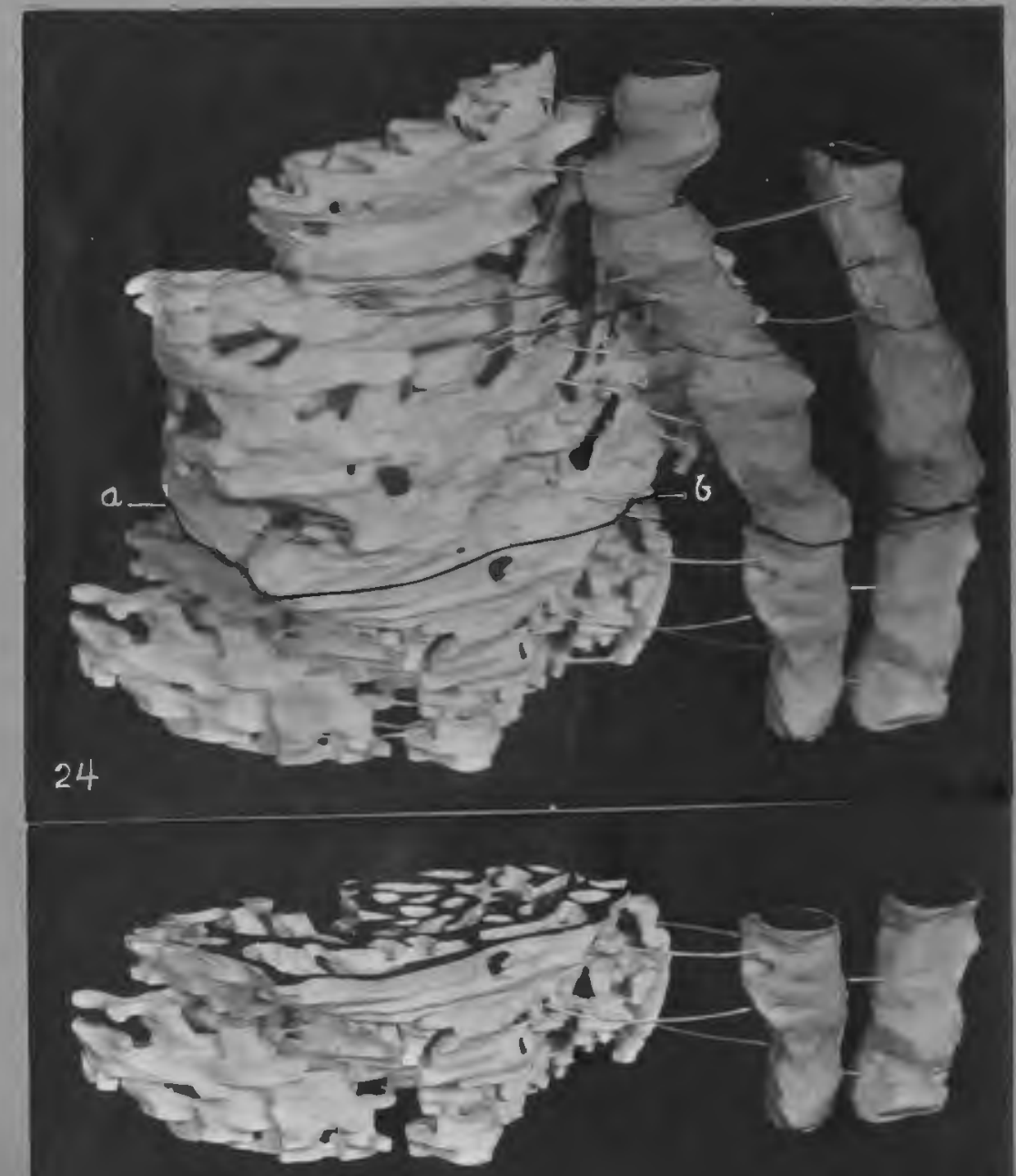

25

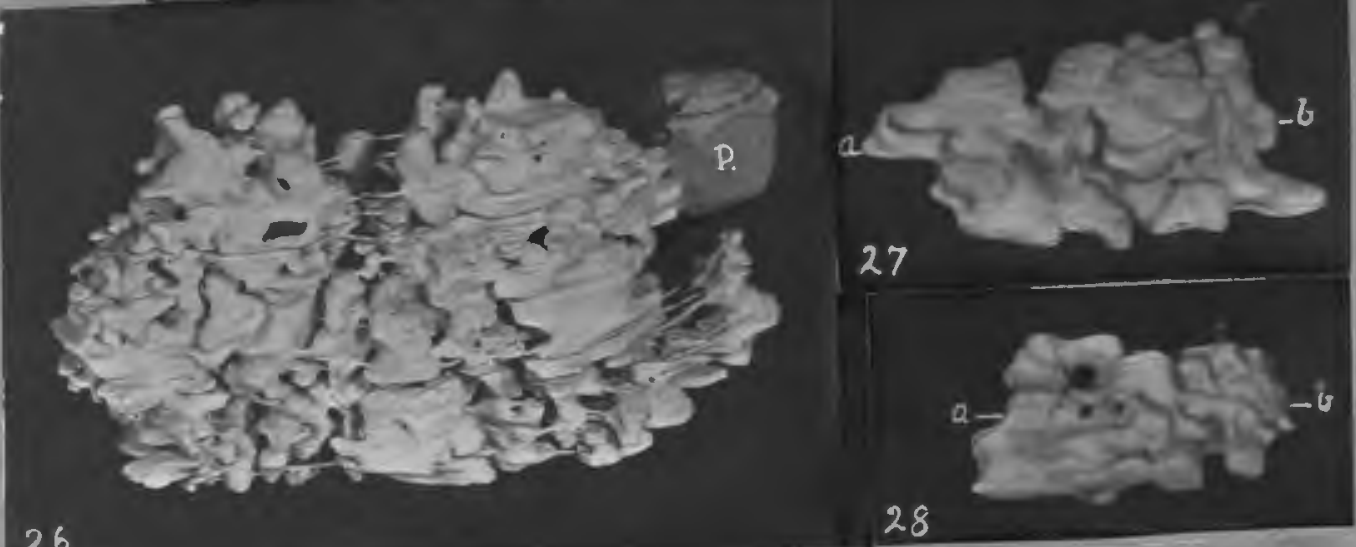



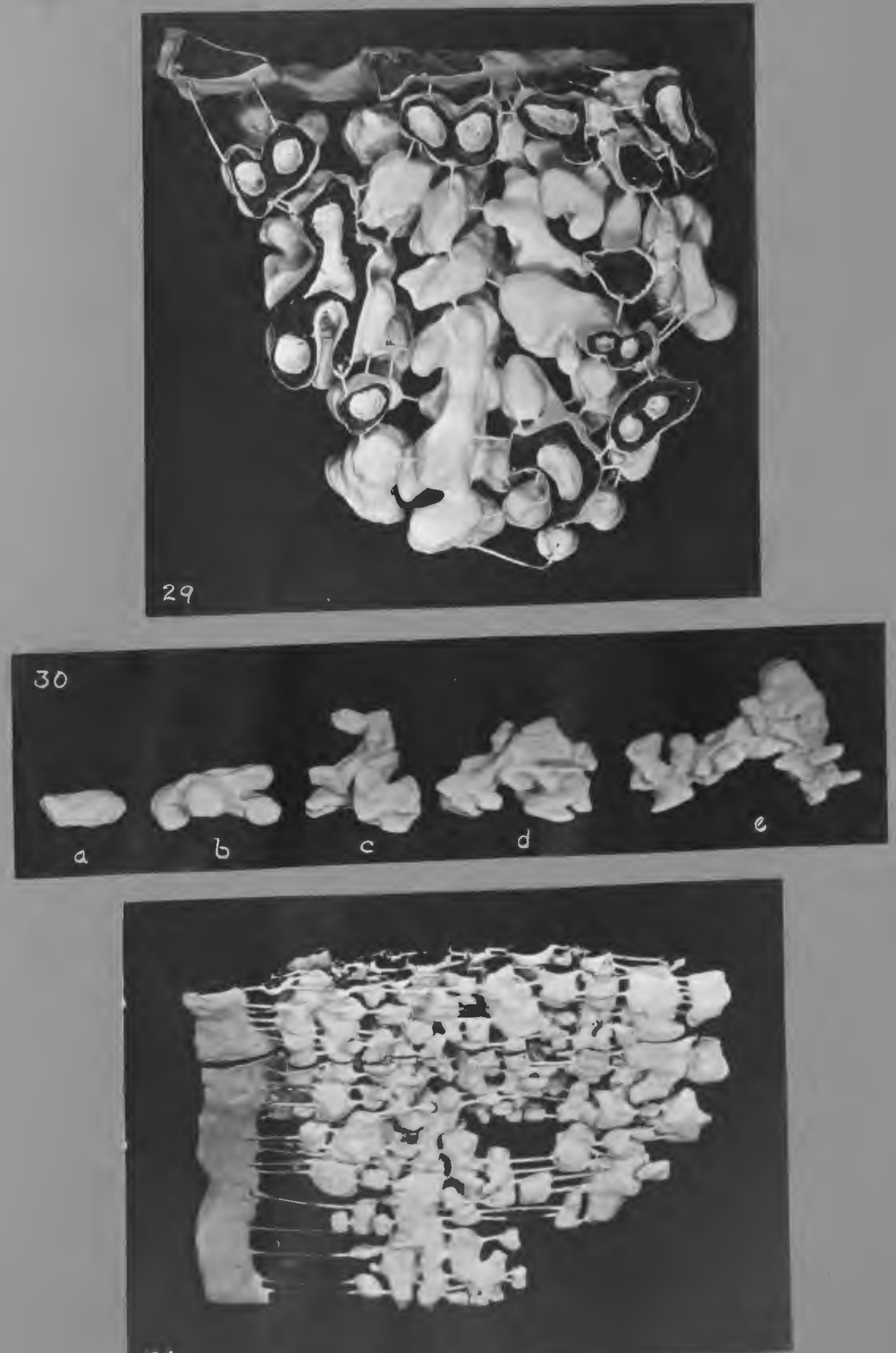